\title{
Resistance Elasticity of Antibiotic Demand in Intensive Care
}

Thomas Heister

Center for Medical Biometry and Medical Informatics, Medical Center - University of Freiburg, Freiburg, Germany
Christian Hagist

WHU - Otto Beisheim School of Management
Klaus Kaier

Center for Medical Biometry and Medical Informatics, Medical Center - University of Freiburg, Freiburg, Germany

WHU - Working Paper

Series in Economics 


\title{
Resistance Elasticity of Antibiotic Demand in Intensive Care*
}

\author{
Thomas Heister
}

Center for Medical Biometry and Medical Informatics, Medical Center - University of Freiburg, Freiburg, Germany

\section{Christian Hagist}

Chair of Intergenerational Economic Policy, WHU - Otto Beisheim School of Management, Vallendar, Germany

\author{
Klaus Kaier \\ Center for Medical Biometry and Medical Informatics, Medical Center - University of \\ Freiburg, Freiburg, Germany
}

February 2015

Key Words: Antimicrobial Resistance; German Intensive Care Units; Health Economics JEL-Classification: I11

\footnotetext{
* Corresponding author: Klaus Kaier; kaier@imbi.uni-freiburg.de; Tel.: +49 (0)761 203-6807; Fax: +49 (0)761 2036711. We thank the association of family firms ASU - Die Familienunternehmer for financial support. Furthermore, we thank Elisabeth Meyer and Frank Schwab for providing the dataset as well as Elisabeth Meyer and Werner Vach for helpful comments regarding the analysis. All errors remain our own.
} 


\section{Abstract}

The emergence and spread of antimicrobial resistance (AMR) is still an unresolved problem worldwide. The most visible effect of AMR, healthcare-associated infections (HAIs), imposes a substantial financial burden on the healthcare system through exacerbation or prolongation of illness and subsequent in-hospital treatment. The impact of the emergence and spread of AMR, however, is not limited to an increase in the number of HAls. AMR also impacts patients who do not become infected. As in-hospital resistance patterns change over time, rationale weighting induces decision-makers to adjust their behaviour in order to provide the best possible treatment in a changing environment of resistance. In settings where resistant organisms are prevalent, for instance, physicians routinely change empirical antibiotic therapy in accordance to the relevant resistance indicator, leading to differences in costs, dosing schedules, and/or side-effect profiles.

The effects of such resistance-induced antibiotic substitution effects are highly relevant in intensive care units (ICUs) where treatment failure often has severe consequences. In ICU settings, first line antibiotic therapy is highly standardized and widely empiric. On the other hand, there is a limited number of reserve antibiotics, whose prices and/or side effects are substantially higher than first-line therapy. We hypothesize that a rise in resistance to first line agents increases demand for the respective reserve agents. In order to provide first estimates of these resistance-induced substitution effects, we conducted a panel data regression analysis on monthly antibiotic use and resistance data from 66 ICUs between 2001 and 2012 .

We chose an estimation using unit-fixed effects and selected combinations of first line agents and their substituting reserve agent in accordance with an expert opinion-guided and predefined set of variables. The investigated reserve antibiotics (Carbapenems, Glycopeptides and Linezolid) represent a large part of all reserve antibiotics and on average $15 \%$ of all prescribed antibiotics.

The findings of the three core regressions support the hypothesis that demand for antibiotics significantly increases when lower level resistance rises. For some regressions the lagged effect of resistance is also significant, supporting the conjecture that part of the substitution effect is caused by physicians changing antibiotic choices in empiric treatment by adapting their resistance expectation to new information on resistance prevalence. In contrast, there is no lagged effect related to the occurrence of methicillin-resistant Staphylococcus aureus (MRSA). This may be explained by the availability of rapid testing, which is increasingly used to immediately screen patients for MRSA, commonly resulting in definitive therapy being promptly available.

The results are robust to different specifications of the empirical model, and the findings imply that expectations play an important role in the demand for antibiotics. For policy makers, an important finding may be that the availability and accuracy of information about prevalence of pathogens and resistance rates can increase treatment optimality by allowing physicians to efficiently balance the trade-off of resistance and treatment success. 


\section{Introduction}

The emergence and spread of antimicrobial resistance (AMR) is still an unresolved problem worldwide. The most visible effect of AMR, healthcare-associated infections (HAls), are considered the most frequent adverse event in health care delivery (European Centre for Disease Prevention and Control 2008). HAls caused by multidrug-resistant bacteria impose a substantial financial burden on the healthcare system through exacerbation or prolongation of illness and subsequent in-hospital treatment (Smith et al. 2005; Shorr 2007; Kaier et al. 2008). This direct medical and financial burden of AMR has been described in a large basket of empirical studies (Maragakis et al. 2008). It was however recently postulated that the current state of research is incomplete and strongly underestimates the true burden of resistance (Smith and Coast 2012; Smith and Coast 2013). Specifically, it was argued that "the reason that current estimates of the cost of resistance are modest is that they are based loosely on the 'incremental' cost related to the extra treatment of resistant over susceptible primary infections" (Smith and Coast 2012, p. 3), and that "... antibiotic resistance has fallen victim to evidence-based policy making [because] health economists have been unable to show that antibiotic resistance costs enough to be a health priority." (Smith and Coast 2013, p. 1).

A comprehensive evaluation of the burden of AMR requires an understanding of the determinants and impact of antibiotic prescription patterns as the key driver of resistance (Monnet et al. 2004; Kaier et al. 2009). Application of antibiotics incurs negative externalities by increasing AMR and thereby lowering the overall efficacy of antibiotics to combat bacterial infections (Laxminarayan and Brown 2001). A key aspect of this negative externality is that by inducing resistance, contemporary antibiotic use alters the likelihood of future treatment 
success of an agent (Phelps 1989; Elbasha 2003; Kaier and Frank 2010). If antibiotic application regimes remained unchanged this means that a rise in resistance would cause an increase in treatment failures (French 2010). However, as in-hospital resistance patterns change over time, rationale weighting induces decision-makers to adjust their behaviour in order to provide the best possible treatment in a changing environment of resistance. Wang and Lipsitch (2006) show conceptually that physicians face a dynamic trade-off in their treatment decisions between maximizing treatment success by choosing the most potent antibiotic on the one hand, and the goal of preserving the efficacy of reserve agents to be able to treat severe infections in the future on the other hand. The optimal choice therefore crucially depends on the likelihood of treatment success as determined by the prevailing resistance rates.

In the available literature, resistance-induced adjustment reactions are often postulated as having a major influence on modern health care delivery (Howard et al. 2001; Howard et al. 2003; Howard 2004; Laxminarayan and Malani 2007; Smith and Coast 2012; Smith and Coast 2013), but rarely addressed in empirical works (Howard 2004; Filippini and Masiero 2012). The implications of this substitution effect are highly relevant for the hospital and specifically the intensive care sector where treatment failure often has severe consequences and resistance selection pressure is more intense than in the outpatient settings (French 2010). Although some studies mention the effect as a determinant of antibiotic demand (Filippini and Masiero 2012; DiazGranados et al. 2008; Huttner et al. 2013) there as of yet exists, to the best of our knowledge, no empirical analysis on the resistance elasticity of antibiotic demand in the hospital sector. 


\section{The model}

This section builds on preliminary works on antibiotic choice among physicians (Howard 2004; Wang and Lipsitch 2006; Filippini and Masiero 2012). The model is an adaption and extension of the one presented by (Howard 2004). For simplicity, physicians and patients are treated as being one and the same in order to avoid agency issues. The utility for every patient receiving drug $j, j \in\{1, \ldots J\}$ may be $v_{j}$ and is defined as a function of the resistance level of drug $j, r_{j}$ the cost of drug $j, c_{j}$, as well as the excess cost of treatment failure $p_{f}$ through exacerbation or prolongation of illness and subsequent in-hospital treatment. Accordingly, the expected utility of patients receiving drug $j$ may be formulated as follows:

$$
v_{j}=\left(1-r_{j}\right)\left(-c_{j}\right)+r_{j}\left(-c_{j}-p_{f}\right)=-c_{j}-r_{j} p_{f}
$$

The cost of antibiotic $\mathrm{j}, c_{j}$ can now be divided into internal and external cost so that $c_{j}=p_{j}+$ $e x_{j}$. The internal cost $p_{j}$ includes all treatment-related expenditure such as the drug price and the costs of administering the drug. External costs are given by $e x_{j}$. This accounts for the societal burden that each antibiotic $j$ causes by increasing resistance and thereby lowering the overall efficacy of antibiotics (Herrmann and Gaudet 2009). The model can therefore be extended into:

$$
v_{j}=\left(1-r_{j}\right)\left(-p_{j}-e x_{j}\right)+r_{j}\left(-p_{j}-e x_{j}-p_{f}\right)=-p_{j}-e x_{j}-r_{j} p_{f}
$$

Please note that this formulation applies only in instances of empirical antibiotic therapy where the physician does not know whether the patient is infected with a resistant strain. In addition to the drug-specific aspects of resistance, this formulation may be further extended with patient-specific consequences of receiving drug $j$. Let $\varepsilon_{i j}$ be a vector capturing drug 
interactions, side effects, convenience and other drug characteristics that vary by patient. Total utility, $V_{i j}$ is then

$$
V_{i j}=v_{j}-\varepsilon_{i j}=-p_{j}-e x_{j}-r_{j} p_{f}-\varepsilon_{i j}
$$

When analysing the choice between two antibiotics, for instance, demand for drug 1 is then

(4) $D_{1}=1-F\left(V_{2}-V_{1}\right)=1-F\left(-p_{2}-r_{2} p_{f}-e x_{2}-\varepsilon_{i 2}+p_{1}+r_{1} p_{f}+e x_{1}+\varepsilon_{i 1}\right)$

Rewriting this and assuming that agent 1 is a reserve antibiotic ${ }^{1}$, while 2 represents a first line antibiotic, gives:

$$
D_{1}=1-F\left(\left(p_{1}-p_{2}\right)+\left(r_{1}-r_{2}\right) p_{f}+\left(e x_{1}-e x_{2}\right)+\left(\varepsilon_{i 1}-\varepsilon_{i 2}\right)\right)
$$

This illustrates that the demand for drug 1 may be seen as a trade-off between the differential characteristics of antibiotic 1 and 2; namely the drug prices $\left(p_{1}-p_{2}\right)$, the expected costs of treatment failure $\left(r_{1}-r_{2}\right) p_{f}$, the external effects $\left(e x_{1}-e x_{2}\right)$, and the expected number of patient-specific side effects $\left(\varepsilon_{i 1}-\varepsilon_{i 2}\right)$. The first term is assumed to be positive, as agents of lower activity are usually cheaper both in terms of direct medication and indirect administration costs. Being a defining feature of reserve antibiotics the difference between the resistance levels is negative. The external costs are assumed to be higher for the reserve antibiotics, as their use exacerbates resistance towards treatment options of last resort, severely affecting intensive care medicine. Therefore it is generally suggested that reserve antibiotics be used prudently so as to preserve their activity for severe cases (Wang and Lipsitch 2006). Finally, reserve agents often cause stronger side effects than non-reserve antibiotics.

\footnotetext{
${ }^{1}$ Reserve antibiotics are agents which have activity against a broad range of pathogens and, most importantly, little resistance to face.
} 
From equation (5) it can be seen that stronger agents are only used if the positive effect of a higher probability of treatment success as given by the resistance difference outweighs the negative aspects of higher internal and external costs as well as stronger side-effects. Keeping all other things equal, it can then be shown that a rise in resistance to first line agents $\left(r_{2}\right)$ increases demand for the reserve agents, while a rise of resistance to them $\left(r_{1}\right)$ decreases demand. Given their nature as antibiotics of last resort, however, resistance to them $\left(r_{1}\right)$ may be of minor impact when analysing the demand for reserve antibiotics. The cost of treatment failure $\left(p_{f}\right)$ enhances the benefit of switching to a reserve antibiotic, thereby positively influencing the level of demand for drug 1 at a given resistance difference.

In ICU settings, first line antibiotic therapy is highly standardized and widely empiric (Meyer et al. 2010). On the other hand, there is a limited number of reserve antibiotics, whose prices and/or side effects are substantially higher than first-line therapy. Assuming differences in drug prices and expected side effects as constant over time, the reduced form demand function for uses of reserve antibiotics $q_{R}$ over time $t$ is shown in Formula (6) making estimation based on aggregated product-level data feasible.

$$
q_{R t}=\beta_{0}+\beta_{1} r_{R t}+\beta_{2} r_{F t}+u_{t}
$$

In detail, $r_{R t}$ is the clinically relevant resistance level of the reserve antibiotic while $r_{F t}$ is a vector of the resistance levels for the most relevant first-line antibiotics and pathogens, to which the reserve antibiotic may be seen as antibiotic of last resort. $u_{t}$ represents the error term. The demand function for uses of reserve antibiotics $q_{R}$ over time $t$ in different settings $k$ may be specified analogously:

(7) $\quad q_{R t}=\beta_{0}+\beta_{1} r_{R k t}+\beta_{2} r_{F k t}+u_{k t}+e_{k t}$

$u_{k t}$ now represents the between-entity error, while $e_{k t}$ represents the within-entity error. 


\section{Empirical Analysis}

\subsection{Data}

To identify the resistance-elasticity of antibiotic demand, a panel data regression analysis is conducted on data from German intensive care units (ICUs) between 2001 and 2012. Understanding the relationship between resistance and antibiotic administration is particularly important in intensive care, where high application density and immuneweakened hosts create both high selection pressure and higher morbidity from infections (French 2010). The analysis exploits a unique dataset collected by the Surveillance System of Antibiotic Use and Bacterial Resistance in Intensive Care Units (SARI). Starting in 2001, the project has gathered monthly data on resistance rates and antibiotic use for participating ICUs in Germany. ${ }^{2}$ The dataset contains 144 time periods, with a total of 66 ICUs from 35 hospitals reporting data. ${ }^{3}$

Resistance rates are calculated by dividing the amount of resistant isolates by the amount of all tested isolates. This measure is useful when investigating the evolution of resistance in pathogens and is important for decision-making in empiric therapy, as it gives the probability that a substance applied will work (Meyer et al. 2013). Pooled resistance densities and resistance rates against a substance class were calculated by constructing weighted averages over the individual resistance variables. Application density $(A D)$ is the amount of Defined Daily Doses (DDD) per 1000 patient days.

\footnotetext{
${ }^{2}$ For a detailed description of SARI and the methods employed in data collection see Meyer et al. (2010).

${ }^{3}$ The panel is unbalanced, with only 11 participating ICUs reporting data every month, the median being 85 months (appendix table A1). Data is collected on doses of all antibiotics used, resistance rates of 13 pathogens towards relevant substances, and patient days per month. See appendix table A2 for the pathogen-resistance combinations collected.
} 


\section{Insert Figure 1: Share of Reserve Antibiotics}

The average antibiotic application density increased from 1240 DDD per 1000 patients in 2001 to 1500 in 2012. The selection of agents used has changed markedly in that time period. Figure 1 shows the use of reserve antibiotics as a share of overall antibiotic application. It increased from $7 \%$ in 2001 to more than $22 \%$ in 2012 . This increase is mostly driven by the nearly threefold increase in application of carbapenems, agents which are active against most gramnegative pathogens. Administration of linezolid and daptomycin, which are used to treat severe infections with resistant gram-positive pathogens, has also significantly increased during the period. This shift in prescription patterns, and particularly the threefold increase in the share of reserve antibiotics, warrants an analysis of whether this was justified by indication. First line drugs are generally preferable treatment choices if pathogen susceptibility is equal. Assuming rational actors, this suggests that the increase in high level antibiotics use would either be caused by a change in pathogen epidemiology towards inherently more resistant types, or by an increase in resistance towards lower level agents while pathogen population is unchanged. Facing treatment failure in definitive medication or expecting it in empiric therapy, physicians might then switch to reserve agents to ensure treatment success. There is no available corresponding data that would allow inference on pathogen prevalence, but figures on pathogen susceptibility do show that resistance against many agents previously administered in severe cases has increased in the last years. In gramnegative pathogens, resistance towards third-generation cephalosporins and fluorochinolones has risen more than twofold between 2001 and 2012, rendering them increasingly ineffective for treatment. Third-generation cephalosporins and fluoroquinolones are broad spectrum antibiotics routinely used to treat severe gram-negative infections in hospitals. Together, they account for $20-25 \%$ of all agents applied in ICUs, and this share has 
remained fairly stable over time. Carbapenems are often the antibiotic of choice if these agents are expected or known to face resistance in treating gram-negative pathogens (Frank and Tacconelli 2012). The increase in the use of highly active gram-negative last resort agents like carbapenems might then be explained by physicians substituting away from less potent antibiotics like cephalosporins in empiric and definitive treatment. Figure 2 shows how the increase in resistance to cephalosporins and fluorochinolones coincides with a similar increase in carbapenem applications. ${ }^{4}$

\section{Insert Figure 2: Carbapenem use and resistance of gram-negatives pathogens to third gen. cephalosporins and fluoroquinolones}

Similar trends can be observed for high level resistance in gram-positive pathogens and use of reserve antibiotics. Figure 3 shows the correlation of linezolid use and vancomycin resistance in enterococcus (VRE), the most prevalent form of glycopeptide resistance in intensive care. Although glycopeptides themselves may be considered a reserve antibiotic for the treatment of, among others, MRSA, linezolid is considered a last resort antibiotic replacing glycopeptides in some specific cases. Although glycopeptide resistance is at very low levels compared to other agents, it has increased in the last years and has become particularly critical in the form of VRE.

\section{Insert Figure 3: Linezolid use and Vancomycin resistance in Enterococcus (VRE)}

\subsection{Econometric Approach}

The preliminary evidence presented above suggests that the substantial change in prescription patterns towards more powerful agents could be a result of resistance-induced substitution effects, as hypothesized. Antibiotic administration decisions by doctors are made

\footnotetext{
${ }^{4}$ This relationship has been demonstrated in an analysis of the same dataset by Meyer et al. (2010).
} 
with respect to unit level resistance rates rather than aggregate figures, so that an aggregate perspective may yield an incomplete picture. We therefore analyse the relationship between resistance and antibiotic applications at the respective unit levels. Exemplary for the hypothesized substitution effect, Figure 4 shows the correlation between third generation cephalosporin resistance and carbapenem use for a university hospital ICU over a 24 month period. ${ }^{5}$ The two lines show a clear, yet not perfect, positive correlation.

\section{Insert Figure 4: Resistance and Antibiotic application over time for an exemplary ICU for $\mathbf{2 4}$ months}

For the econometric estimation of the effect we conduct a panel data regression analysis. To account for unobserved level differences in antibiotic prescription patterns and resistance rates, we use a fixed effect estimation to disentangle the between-unit differences from dynamic within effects. This differences out any unobserved time invariant factors such as ICU size, location, and general patient structure that might systematically influence the level of antibiotic use and resistance of a unit in all years.

Table 1 gives the descriptive statistics of the main variables in a panel data context. It shows the overall mean of variables as well as between and within section variation. ${ }^{6}$ As within-ICU substitution effects are the focus of the present work we chose an estimation using unit fixedeffects. $^{7}$

\section{Insert Table 1: Descriptive Panel Statistics}

\footnotetext{
${ }^{5}$ For illustrative purposes this naturally only shows a fraction of the sample, as only one unit and a time excerpt is shown. Plotting correlations in a large panel data context is not graphically feasible.

${ }^{6}$ On average, variables change substantially over time in each unit, and this variation is larger than the differences of averages between units. The within unit variation gives the deviation from unit averages. Minima are therefore negative.

${ }^{7}$ Hausman tests were performed and showed fixed effect consistency against random effects.
} 
Three main regressions are conducted in which we analyse the substitution effects towards the use of reserve antibiotics. The first investigates the influence of resistance in gramnegative pathogens on the application of carbapenems. The main independent variables are the pooled resistance rates against third-generation cephalosporins, pooled resistance against second and third generation fluoroquinolones, and resistance to piperacilin/tazobactam. The second and third regressions analyse the resistance-induced substitution in gram-positive antibiotics. Glycopeptide use is investigated with respect to oxacillin resistance in S. aureus (MRSA) and incidence of coagulase-negative Staphylococcus (CNS). ${ }^{8}$ CNS are almost always resistant to all beta-lactamase resistant penicillins and generally require stronger agents for treatment. Finally, we regress linezolid application density on MRSA incidence and vancomycin resistance in Enterococcus (VRE).

The antibiotics on the left hand side are substitutes for the explanatory variables' substance classes in face of increasing resistance. The combinations were chosen based on a review of in-hospital antibiotic guidebooks, which list pathogen-specific first-, second-, and third-line choices for antibiotic therapy in face of increasing resistance (Frank and Tacconelli 2012; Bundesärztekammer 2009). Additionally, an infectious disease physician was consulted for inhospital expertise. ${ }^{9}$ Inclusion of specific resistance rates on the right hand side therefore took place according to a pre-defined set of variables of clinical relevance in line with expert opinion. The investigated antibiotics represent a large percentage of reserve antibiotics and

\footnotetext{
${ }^{8}$ The incidence is given by the tested isolates. A crucial assumption therefore is that the number of tested isolates presents a valid figure for CNS incidence. This was confirmed by an infectious disease specialist of the SARI group.

${ }^{9}$ Theoretically, other antibiotics would also be worth investigating with respect to a change in prescription patterns and resistance rates. However, data availability limited the analysis to the three mentioned above. As resistance rates for lower level substances such as Penicillins, or first and second generation Cephalosporins are not or only selectively collected in the data set, an analysis of the substitution effects between first and second line agents is not feasible (see appendix table A2 for the tested resistance rates). Colistin and Tigecyclin were not tested due to a lack of data variation, as these agents are so rarely used that more than $90 \%$ of observations are zero.
} 
on average $15 \%$ of all prescribed antibiotics. Analysing the resistance-induced substitution effect in the application of these high level agents can help understand the general endogeneity of resistance and antibiotic use and its implications for antibiotic demand.

As the dataset contains monthly observations over a 12 year period, it is necessary to consider the time-series nature of the panel and discuss serial correlation and non-stationarity. ${ }^{10}$ If error terms are serially correlated, then standard errors are inconsistent. Using the panel data test for serial correlation as suggested by Wooldridge (2002) and implemented by Drukker (2003), the null hypothesis of no first-order autocorrelation in the error terms could not be rejected for all three regressions. In addition, a Fisher type unit-root test for panel data, as proposed by Choi (2001), did not find evidence of non-stationarity in the included variables. ${ }^{11}$ There is however some evidence for dependent variable autocorrelation of first order (see appendix Table A3) and some individual time series are stationary. To account for this, we use a dynamic panel model with first order autoregressive disturbance terms. ${ }^{12}$

Another issue is whether or not the resistance rates can be assumed to only influence the antibiotic prescription choice in the current period t. As outlined above, part of the resistanceinduced substitution is likely to be caused by a change in expectation of resistance in empiric therapy as physicians update information about prevailing resistance rates. ${ }^{13}$ The information

\footnotetext{
${ }^{10}$ This is often called a time series cross-sectional dataset, as the time dimension is far more dominant than in many other microeconometric panel data. This has distinct implications for the regression analysis. See Beck and Katz (2011) for a discussion of the general property of this type of dataset.

${ }^{11}$ However, these were aggregate figures and the Fisher type panel unit root test is a weak test that merely implies that at least one process is stationary (Appendix Table A2). Following Pesaran (2012), Augmented Dickey-Fuller tests were additionally conducted for each variable and panel separately. This showed that, although a unit root cannot be rejected for some individual time series, most series are stationary nonetheless.

${ }^{12}$ We chose not to use a lagged dependent variable approach as this could obfuscate the investigated effect when lags of the independent variables are added. Including lagged dependent variables into a fixed effects model additionally biases coefficients Nickell (1981). Although Arellano and Bond (1991) developed a widely used GMM instrumental variable estimation to solve this problem for small microeconometric datasets , there are distinct issues that arise in a large cross-sectional time series context (Judson and Owen 1999).

${ }^{13}$ Investigating the same dataset Meyer et al. (2010)) note that most antibiotic administrations are likely to be empiric, as the mean ICU stay is merely 4 days.
} 
flow regarding resistance could be delayed, so that resistance rates might influence antibiotic application in subsequent periods. When testing this the significant effect was restricted to the first two periods, so that as a general rule the effects of the explanatory resistance rates were additionally estimated using a simple finite distributed lag model for two periods. It is likely that demand for an antibiotic is not only influenced by the resistance rates to first-line level agents, but also by its own resistance as suggested in the model above. As the antibiotics investigated already are reserve agents, however, there often are no other options when ownresistance increases. Additionally, the prevalent resistance rates are comparatively low. Regressions analysing the own-resistance elasticity were performed but showed no significant effect and did not alter the main coefficients of interest. Including a contemporaneous ownresistance variable would by construction be endogenous, as antibiotic use influences resistance as well. A lagged variable of own-resistance would on the other hand introduce collinearity issues arising from the inclusion of multiple lagged variables on the right hand side. These variables are therefore not included.

The baseline $A R(1)$ distributed lags fixed effect regression model to identify the resistance induced substitution effects is then:

$$
Y_{i t}=\alpha+\boldsymbol{R}_{\text {ait }} \boldsymbol{\beta}_{1 a}+\boldsymbol{R}_{\text {ait-1 }} \boldsymbol{\beta}_{2 a}+c_{i}+u_{i t}
$$

with

$$
u_{i t}=\rho u_{i t-1}+\varepsilon_{i t}
$$

$Y_{i t}$ is the application density of the investigated antibiotic used in unit i and month t. ${ }^{14} \boldsymbol{R}_{\text {ait }}$ is a $(1 \times A)$ vector of the pooled resistance rates or resistance densities of antibiotic class $a, a \in$ $\{1,2, \ldots, A\}$, for unit $i, i \in\{1,2, \ldots, N\}$ at time $t, t \in\{1,2, \ldots, T\}$. The main coefficients of interest are

\footnotetext{
${ }^{14}$ These and the following notations are largely adapted from Wooldridge (2010)
} 
thus the $(A \times 1)$ vectors $\boldsymbol{\beta}_{1 a}$ and $\boldsymbol{\beta}_{2 a}$, which measure the induced substitution effect of resistance in antibiotic a in period $\mathrm{t}$ and $\mathrm{t}-1$ respectively. As discussed above, it is reasonable to assume that time invariant factors are somehow correlated with the explanatory variables. The unit fixed-effect $c_{i}$ is therefore estimated to remove all time invariant heterogeneity between the units. ${ }^{15}$ Finally, $u_{i t}$ gives the autoregressive error term while $\varepsilon_{i t}$ is the idiosyncratic error term for unit i and time t.

The fixed effects remove the time invariant unobserved heterogeneity, but do not account for unobserved time specific effects that influence all cross-sections. Events like the market entry of daptomycin in $\mathbf{2 0 0 6}$ might for example systematically influence the prescription of linezolid and glycopeptides, as it presents a therapeutic substitute. To account for this and other unobservable time specific effects like seasonality that could systematically influence antibiotic use or resistance rates, we additionally present a two-way error component fixed effect model by calculating time fixed effect. The remaining identifying variation to explain antibiotic demand is then the differential dynamics of resistance rates across ICUs. We moreover added a third specification including a time trend. All three specifications are separately calculated with and without lagged independent variables for comparison.

\subsection{Results}

Table 2 gives regression results for carbapenem use. Resistance to $3^{\text {rd }}$ generation cephalosporin has a significant contemporaneous effect in the one way error component model. A one percentage point increase in $3^{\text {rd }}$ generation cephalosporin resistance increases carbapenem application density by $.43 \%$. This is a moderate effect considering the substantial

\footnotetext{
${ }^{15}$ The fixed effects model is estimated with a least squares dummy variable (LSDV) approach to be able to obtain consistent $R^{2}$ in Stata.
} 
increase in prevalence of cephalosporin resistance over time. There is no significant effect of the lagged variable. The strong aggregate correlation as depicted in figure 2 then possibly reflects mostly between-unit differences rather than within effects. Moreover, once time fixed effects or a time trend are estimated this effect disappears, suggesting that the measured effect could for example be due to events simultaneously affecting all ICUs or an underlying trend that is independent of the hypothesized effect. Apart from third generation cephalosporins only resistance to Piperacillin/Tazobactam has a significant contemporaneous effect in the first model. No effect is found for second and third generation fluoroquinolone resistance.

\section{Insert Table 2. Resistance Elasticity of Carbapenem Use}

The picture is different for the regressions on Linezolid use as summarized in table 3 . Both MRSA and VRE rates significantly influence the application density of Linezolid in all six specifications. In the one-way error component distributed lag model there is an estimated $0.72 \%$ rise in Linezolid use when MRSA rates increase by one percentage point. An analogous rise in VRE rates is associated with a $1.58 \%$ increase in linezolid application, which is a considerable effect in light of the average prevalence of VRE of around $9 \%$ in 2012. VRE in the previous period also exhibits a statistically and economically significant effect on the application density of around $1.35 \%$ per one percentage point increase. In contrast, MRSA rates do only show a small lagged effect in the model without time effects. Adding period fixed effects to the model slightly reduces the impact of MRSA while coefficients on VRE are roughly half the magnitude, suggesting that some of the effect may have been caused by unobserved time effects.

Insert Table 3. Resistance Elasticity of Linezolid use 
The results for glycopeptide use are given in table 4. Both contemporaneous MRSA rates and CNS incidence have a statistically significant impact on glycopeptide use. However, only CNS has a significant lagged effect. The magnitude is similar across all specifications and varies from about $0.37 \%$ to $0.5 \%$ for the effect of a one percentage point increase in MRSA rates, and from $0.15 \%$ to $0.2 \%$ for the effect of a $1 \%$ rise in CNS incidences, while the lagged effect for CNS is around $0.1 \%$. It is noteworthy that, in contrast to the other regressions, including period fixed effects or a trend variable does not alter results relevantly, suggesting that the estimates do in fact exclusively reflect dynamic within-unit effects of the relation between resistance and antibiotic use irrespective of time effects.

\section{Insert Table 4. Resistance Elasticity of Glycopeptide use}

\section{Discussion}

The results of the three core regressions seem to support the hypothesis that demand for reserve antibiotics significantly increases when lower level resistance rises. For some regressions the lagged effect of resistance was also shown to be significant. This supports the conjecture that part of the substitution effect is caused by physicians changing antibiotic choices in empiric treatment by adapting their resistance expectation to new information on resistance prevalence. It is plausible that this transmission is not instantaneous. The resistance-induced substitution effect caused by adapted definitive treatment can conversely only plausibly be explained by the contemporaneous resistance rates. In this respect demand responsiveness to MRSA may be systematically different to other pathogens as rapid testing is increasingly used to immediately screen patients for MRSA, so that definitive therapy is often possible within a short time period (Harbarth et al. 2006). This may explain why, in contrast to other resistance rates, there was no lagged effect of MRSA in most specifications. 
A critical issue with the dataset is that the variables for linezolid and glycopeptide use present a corner solution outcome. ${ }^{16}$ Being reserve agents, many of the observed unit-month observations pile up at zero. ${ }^{17}$ This is in general adequately addressed by a Tobit regression model to account for the non-continuous nature of the dependent variable. In addition to the linear regression analysis with fixed effect discussed above, we therefore applied two further methods for the regressions on linezolid and glycopeptide use. An unconditional Tobit model with unit dummy variables is generally considered to be biased. However, Greene (2004) shows this bias to be negligible in larger panels even at a degree of censoring around $50 \%$. Consisting of 66 Units, the coefficients should therefore be fairly accurately estimated. Additionally, Honore (1992) developed a Tobit fixed effect estimation, whose implementation however is limited in the available specifications. The results for the Tobit regressions using the two approaches are provided in the appendix in Tables A5 and A6. The specification was limited to a static model as introducing dynamic effects further complicates consistent estimation (Honoré 1993). Available models for dynamic fixed effects Tobit estimations as in Honoré (1993) are not yet implemented in econometric software packages. Both estimations produced fairly similar results, and the average partial effects are almost identical to linear fixed effects estimations in a static specification and only marginally differ from the results presented here. Only for the effect of VRE on Linezolid use does the Tobit model present a significantly larger estimate.

Another potential issue underlying the regressions specification above concerns the resistance measurement. In the context of the presented model of resistance-induced antibiotic substitution it is argued that in empiric therapy a physician chooses an antibiotic with respect

\footnotetext{
${ }^{16}$ See Wooldridge (2010)) for a discussion of the difference between corner solution outcomes and actual data censoring.

${ }^{17}$ For Carbapenems 7,6\%, for Linezolid 44\%, and for Glycopeptides $28 \%$ of observations are zero .
} 
to the probability of treatment success among other things. This was assumed to be accurately represented by the resistance rate variable, which gives the number of resistant isolates to all tested isolates. It therefore indicates the probability of encountering resistance when targeting a pathogen with a specific substance. However, it can be argued that, rather than the actual likelihood of resistance, it is the awareness of resistance cases that influences the physician's drug choice in empiric therapy. To make a rational choice based on the probability of resistance the physician would require up-to-date information on prevailing resistance rates. This assumption may be too strong. Instead, antibiotic choice could be influenced by the physician's awareness of resistance cases in his unit. Resistance density, which gives the resistant isolates per 1000 patient days, would then be a more appropriate measurement. ${ }^{18}$ To test the results above for robustness we additionally conducted the regressions using resistance density variables instead of resistance rates. The results are given in tables A7 A19 in the appendix.

The results for Carbapenem use differ in that fluoroquinolone resistance can now be shown to significantly influence application of carbapenems in all specifications when using resistance density measures. The effect is however fairly small at less than $0.1 \%$ increase in application for a $1 \%$ increase in resistance density. Lagged MRSA rates can moreover be shown to significantly influence linezolid and glycopeptide application while other variables are similar with respect to significance and direction of the effect. ${ }^{19}$ It is not evident where this difference stems from, but potentially for fluorochinolone resistance and MRSA it is less the resistance rate than the prevalence of cases that influences antibiotic treatment decisions.

\footnotetext{
18 Nonetheless, for the resistance induced substitution in definitive as opposed to empiric treatment, the resistance rate is a more adequate measure as it gives the likelihood that for a given pathogen the blood test will reveal that a specific substance is ineffective, therefore necessitating a stronger agent.

${ }^{19}$ A direct comparison of the magnitude of the coefficients between the two resistance measures is not meaningful as one is the percentage point elasticity while the other gives the percentage change elasticity.
} 
This certainly makes sense for MRSA as it is the most prevalent and known resistant pathogen in the intensive care setting, so that physician may be more sensitive to an increase in these cases.

A potential caveat in all regressions is cross-resistance, which can cause collinearity in the explanatory variables. If resistance towards one substance class is accompanied by resistance to another, it is hard to disentangle the two effects in a regression. This could possibly explain why, in contrast to the preliminary conjecture, fluoroquinolone resistance rates cannot be shown to influence carbapenem consumption when cephalosporin and piperacillin/tazobactam resistance is accounted for. The exclusion of third generation cephalosporin and piperacillin/tazobactam resistance in the regression of Table 2, for instance, leads to a significant point estimate of $2^{\text {nd }}$ and $3^{\text {rd }}$ generation fluoroquinolone resistance. A one percentage point increase in resistance is then accompanied by an approximate $0.38 \%(p<0.01)$ increase in carbapenem use in the one-way error component model (Appendix Table A10).

A crucial assumption concerning the nature of the panel data is that its unbalancedness is not due to systematic reasons. Data gaps may bias the results, if their occurrence is correlated to the idiosyncratic error terms. Likewise, if time series are later added or retracted selectively for time varying characteristics, outcomes are biased in a similar manner. Moreover, the unbalanced nature of the data could pose a problem if the process of reporting data itself influences prescription behaviour in the respective unit. In the last decades, for instance, it has been shown that the existence of a surveillance system itself prevents nosocomial infections (Haley et al. 1985; Pittet et al. 2005; Gastmeier et al. 2006; Pittet et al. 2005). If SARI participation leads to increased efforts to record and report resistance rates within the ICU, then the resistance-responsive antibiotic prescription patterns may be systematically 
different for units that have been part of the panel for a longer time than for newly added ones. Self-selection can also prevent causal inference if ICUs decide to participate in the program or leave it for reasons correlated with the time varying unobserved effect. The researchers collecting the data have however confirmed that to the best of their knowledge there are no systematic patterns that cause the unbalancedness, but rather that administrative issues are at the root.

The findings show that demand for antibiotics is responsive to underlying resistance rates. This necessarily gives an incomplete picture of the total demand for antibiotics, as other factors such as disease epidemiological, pharmacological aspect, and antibiotic prices were not taken into account. However, as the analysis was restricted to intensive care units, it is likely that compared to other in- and outpatient settings, treatment success, as given by the susceptibility of pathogens to a substance, plays the most important role in demand for antibiotics.

\section{Conclusion}

The major aim of this study was to analyse the demand characteristics of antibiotics in the ICU setting. To test whether actual and expected pathogen resistance influences antibiotic demand, we conducted a panel data analysis to quantify resistance-induced substitution effects. The hypothesis that increasing resistance in first-line agents increases the use of reserve agents was generally supported by the results, although not for all analysed resistance rates. For some antibiotics, resistance in the previous period was also shown to significantly influence antibiotic prescription patterns. This supports the conjecture that part of the substitution effect is caused by an adapted resistance expectation in empiric treatment rather than a changed administration in definitive therapy after tests have revealed the susceptibility 
of the pathogen. The findings suggest that the substantial increase observed in reserve antibiotic application can at least partly be explained by an increase in resistance to first and second-line agents. By and large, the results were shown to be robust to different specifications of the empirical model.

The findings imply that expectations play an important role in the demand for antibiotics as physician do not know a pathogen's antibiotic susceptibility in empiric therapy. This has gained little attention in the context of antibiotic resistance and stewardship. For policy makers, an important implication of this is that the availability and accuracy of information about prevalence of pathogens and resistance rates can increase treatment optimality by allowing physicians to efficiently balance the trade-off of resistance and treatment success (Kollef 2000). This may be reflected in the increase in surveillance efforts across the world. ${ }^{20}$ Improving diagnostic methods in terms of accuracy and speed can also increase treatment efficiency by allowing prompt, definitive treatment based on pathogen and susceptibility information (Klein et al. 2007).

Economically, the findings imply that resistance can increase costs by causing a substitution towards stronger agents, which are often more expensive in direct terms. This effect was analysed by Howard (2004) for the outpatient sector. In intensive care settings, indirect costs of stronger medication, such as more expensive administration procedures and additional necessary care, are likely to play a larger role. To accurately account for the full burden of resistance, it is necessary to incorporate the direct and indirect costs of stronger medication caused by the substitution effect.

\footnotetext{
${ }^{20}$ See e.g. ECDC (2013), GERMAP (2014) and WHO (2014).
} 
For the modelling of antibiotic resistance the analysis suggests that antibiotic use is endogenous with respect to resistance, as argued by Howard (2004). Apart from the biological effect that use exacerbates resistance, it is resistance that in turn crucially influences the use of antibiotics. Neglecting this prevalence-dependent behaviour in antimicrobial prescribing can overstate resistance predictions to a specific substance Howard (2004). Empirically, it was shown that econometric methods can be a fruitful tool for the analysis of the dynamic relation between antibiotic use and resistance in a panel data context, so as to isolate causal dynamic effects and to quantify responsiveness.

Please note that the conducted empirical analysis rests on some simplifying assumptions about the process of in-hospital antibiotic prescription and the microbiological relation between antibiotic use and resistance. This level of abstraction, albeit necessary in this context, can neglect important other determinants of the antibiotic prescription process. It is therefore important to interpret the presented results cautiously in context of the complex incentive structures present in the medical sector. Nonetheless, the economic and econometric approach to modelling antibiotic demand with respect to susceptibility has presented some useful insights into a topic which is of critical importance to the future of medical care, public health, and the economy. 


\section{Bibliography}

Arellano M, Bond S. 1991. Some Tests of Specification for Panel Data: Monte Carlo Evidence and an Application to Employment Equations. The Review of Economic Studies 2 : 277-297.

Beck N, Katz J N. 2011. Modeling Dynamics in Time-Series-Cross-Section Political Economy Data. Annual Review of Political Science 1 : 331-352.

Bundesärztekammer (2009). Arzneiverordnungen. Empfehlungen zur rationalen Pharmakotherapie. $22^{\text {nd }}$ ed. Neu-Isenburg: MMI - Medizinische Medien Informations GmbH.

Choi I. 2001. Unit root tests for panel data. Journal of International Money and Finance 2 : 249-272.

DiazGranados C A, Cardo D M, McGowan J E. 2008. Antimicrobial resistance: international control strategies, with a focus on limited-resource settings. International Journal of Antimicrobial Agents $1: 1-9$.

Drukker D M. 2003. Testing for serial correlation in linear panel-data models. Stata Journal 2 : 168 177.

Elbasha E H. 2003. Deadweight loss of bacterial resistance due to overtreatment. Health Economics 2 : 125-138.

European Centre for Disease Prevention and Control (2008). Annual Epidemiological Report on Communicable Diseases in Europe 2008. Stockholm.

European Centre for Disease Prevention and Control (ECDC) (2013). Antimicrobial resistance surveillance in Europe 2012. Annual report of the European Antimicrobial Resistance Surveillance Network (EARS-Net). ECDC. Stockholm.

Filippini M, Masiero G. 2012. An empirical analysis of habit and addiction to antibiotics. Empirical economics 2 : 471-486.

Frank Uwe,Tacconelli Evelina (2012). The Daschner guide to in-hospital antibiotic therapy. With 6 tables; [European standards ; 2012-2013]. 2. ed. Heidelberg: Springer Medizin.

French G L. 2010. The continuing crisis in antibiotic resistance. International Journal of Antimicrobial Agents $0: 3-7$.

Gastmeier P, Geffers C, Brandt C, Zuschneid I, Sohr D, Schwab F et al.. 2006. Effectiveness of a nationwide nosocomial infection surveillance system for reducing nosocomial infections. Journal of Hospital Infection 1 : 16-22.

GERMAP (2014). Antibiotika-Resistenz und -Verbrauch 2012. Bericht über den Antibiotikaverbrauch und die Verbreitung von Antibiotikaresistenzen in der Human- und Veterinärmedizin in Deutschland. Edited by Paul Ehrlich Gesellschaft für Chemotherapie.

Greene W. 2004. Fixed Effects and Bias Due to the Incidental Parameters Problem in the Tobit Model. Econometric Reviews 2 : 125-147.

Haley R W, Culver D H, White J W, Morgan W M, Emori T G, Munn V P, Hooton T M. 1985. The efficacy of infection surveillance and control programs in preventing nosocomial infections in US hospitals. American Journal of Epidemiology 2 : 182-205.

Harbarth S, Masuet-Aumatell C, Schrenzel J, Francois P, Akakpo C, Renzi G et al.. 2006. Evaluation of rapid screening and pre-emptive contact isolation for detecting and controlling methicillinresistant Staphylococcus aureus in critical care: an interventional cohort study. Critical Care $\mathbf{1}$ : R25.

Herrmann M, Gaudet G. 2009. The economic dynamics of antibiotic efficacy under open access. Journal of Environmental Economics and Management 3 : 334-350.

Honore B E. 1992. Trimmed Lad and Least Squares Estimation of Truncated and Censored Regression Models with Fixed Effects. Econometrica 3 : p. 533.

Honoré B E. 1993. Orthogonality conditions for Tobit models with fixed effects and lagged dependent variables. Journal of Econometrics 1-2 : 35-61.

Howard D, Cordell R, McGowan Jr, John E, Packard R M, R Douglas Scott, II, Solomon S L. 2001. Measuring the economic costs of antimicrobial resistance in hospital settings: summary of the Centers for Disease Control and Prevention-Emory Workshop. Clinical Infectious Diseases : 15731578. 
Howard D H. 2004. Resistance-induced antibiotic substitution. Health Economics 6 : 585-595.

Howard D H, Scott R D, Packard R, Jones D. 2003. The global impact of drug resistance. Clinical Infectious Diseases Supplement 1 : S4-S10.

Huttner A, Harbarth S, Carlet J, Cosgrove S E, Goossens H, Holmes A et al.. 2013. Antimicrobial resistance: a global view from the 2013 World Healthcare-Associated Infections Forum. Antimicrobial Resistance and Infection Control 2.

Judson R A, Owen A L. 1999. Estimating dynamic panel data models: a guide for macroeconomists. Economics Letters 1 : 9-15.

Kaier K, Frank U. 2010. Measuring the externality of antibacterial use from promoting antimicrobial resistance. Pharmacoeconomics $12: 1123-1128$.

Kaier K, Hagist C, Frank U, Conrad A, Meyer E. 2009. Two Time-Series Analyses of the Impact of Antibiotic Consumption and Alcohol-Based Hand Disinfection on the Incidences of Nosocomial Methicillin-Resistant Staphylococcus aureus Infection and Clostridium difficile Infection. Infection Control and Hospital Epidemiology 4 : 346-353.

Kaier K, Wilson C., Chalkley M, Davey P, Suetens C, Grundmann H et al. 2008. Health and Economic Impacts of Antibiotic Resistance in European Hospitals - Outlook on the BURDEN Project. Infection 36 : 492-494.

Klein E, Laxminarayan R, Smith D L, Gilligan C A. 2007. Economic incentives and mathematical models of disease. Environment and Development Economics 05 : 707-732.

Kollef M H. 2000. Inadequate antimicrobial treatment: an important determinant of outcome for hospitalized patients. Clinical Infectious Diseases : 131-138.

Laxminarayan R, Brown G M. 2001. Economics of Antibiotic Resistance: A Theory of Optimal Use. Journal of Environmental Economics and Management 2 : 183-206.

Laxminarayan Ramanan,Malani Anup (2007). Extending the Cure: Policy responses to the growing threat of antibiotic resistance: Earthscan.

Maragakis L L, Perencevich E N, Cosgrove S E. 2008. Clinical and economic burden of antimicrobial resistance. Expert Review of Anti-infective Therapy $5:$ 751-763.

Meyer E, Gastmeier P, Deja M, Schwab F. 2013. Antibiotic consumption and resistance: data from Europe and Germany. International Journal of Medical Microbiology 6 : 388-395.

Meyer E, Schwab F, Schroeren-Boersch B, Gastmeier P. 2010. Dramatic increase of third-generation cephalosporin-resistant E. coli in German intensive care units: secular trends in antibiotic drug use and bacterial resistance, 2001 to 2008. Critical Care 3 : R113.

Monnet D L, MacKenzie F M, López-Lozano J M, Beyaert A, Camacho M, Wilson R et al.. 2004. Antimicrobial Drug Use and Methicillin-resistant Staphylococcus aureus, Aberdeen, 1996-2000. Emerging Infectious Diseases 8 : 1432-1441.

Nickell S. 1981. Biases in dynamic models with fixed effects. Econometrica : 1417-1426.

Paladino J A, Sunderlin J L, Price C S, Schentag J J. 2002. Economic Consequences of Antimicrobial Resistance. Surgical Infections 3 : 259-267.

Pesaran M H. 2012. On the interpretation of panel unit root tests. Economics Letters 3 : 545-546.

Phelps C E. 1989. Bug/Drug Resistance: Sometimes Less is More. Medical Care 2 : 194-203.

Pittet D, Allegranzi B, Sax H, Bertinato L, Concia E, Cookson B et al. 2005. Considerations for a WHO European strategy on health-care-associated infection, surveillance, and control. The Lancet Infectious Diseases $4: 242-250$.

Shorr A F. 2007. Epidemiology and economic impact of meticillin-resistant Staphylococcus aureus. Pharmacoeconomics 9 : 751-768.

Smith R, Coast J. 2013. The true cost of antimicrobial resistance. British Medical Journal : 1-5.

Smith R D, Coast J. 2012. The economic burden of antimicrobial resistance: why it is more serious than current studies suggest. Edited by London School of Hygiene and Tropical Medicine. London.

Smith R D, Yago M, Millar M, Coast J. 2005. Assessing the macroeconomic impact of a healthcare problem: The application of computable general equilibrium analysis to antimicrobial resistance. Journal of Health Economics : 1055-1075.

Wang Y C, Lipsitch M. 2006. Upgrading antibiotic use within a class: Tradeoff between resistance and treatment success. Proceedings of the National Academy of Sciences 25 : 9655-9660. 
Wooldridge Jeffrey M. (2002). Econometric analysis of cross section and panel data. Cambridge, Mass: MIT Press.

Wooldridge Jeffrey M. (2010). Econometric analysis of cross section and panel data. 2 nd ed.

Cambridge, Mass: MIT Press.

World Health Organization (WHO) (2014). Antimicrobial resistance: global report on surveillance. Geneva. 


\section{Figures and Tables}

Figure 1: Share of Reserve Antibiotics
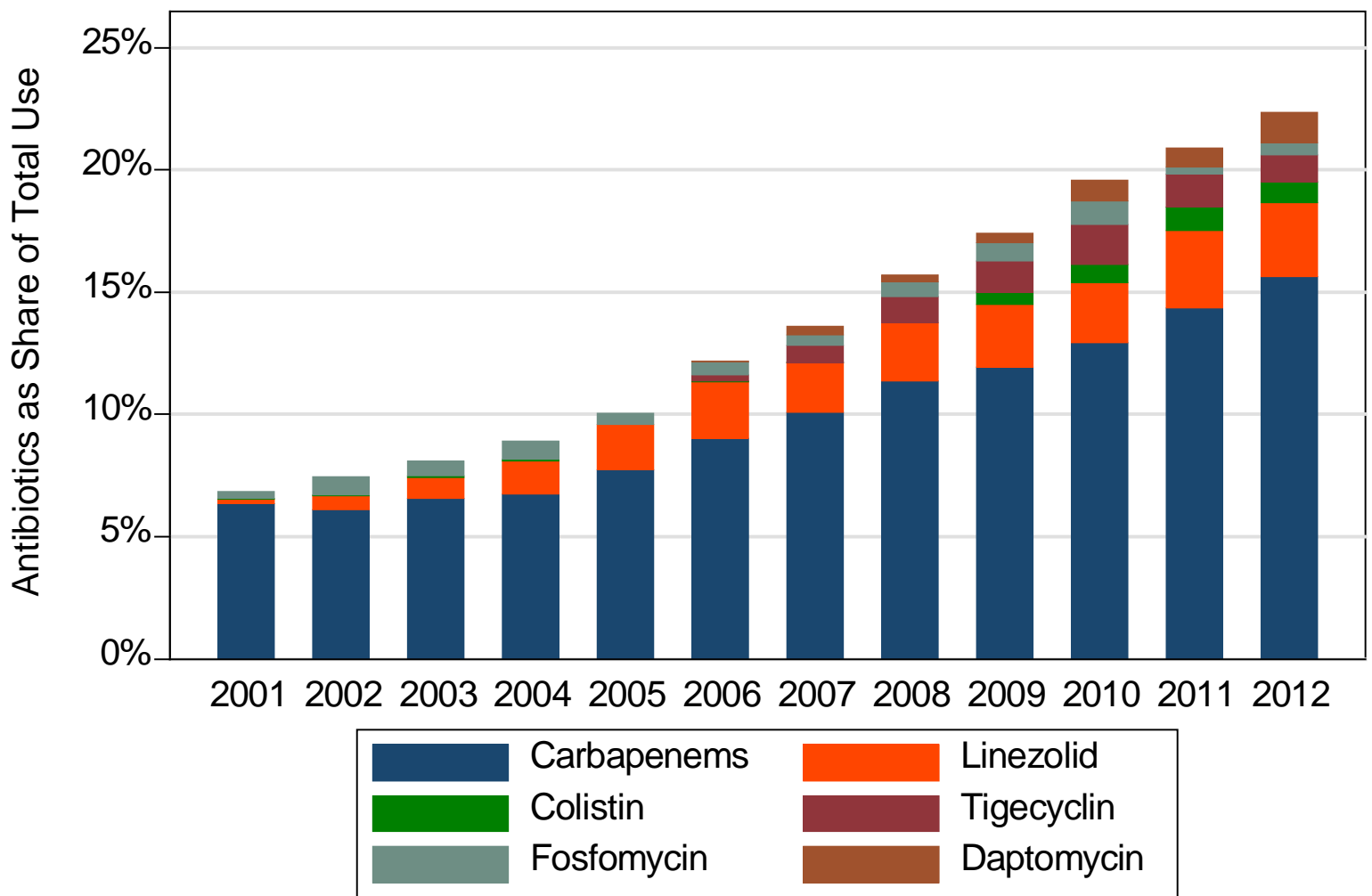

Note: Tigecylcin and Daptomycin entered the German market in 2006

Figure 2: Carbapenem use and resistance of gram-negatives pathogens towards third gen. cephalosporins and Fluoroquinolones

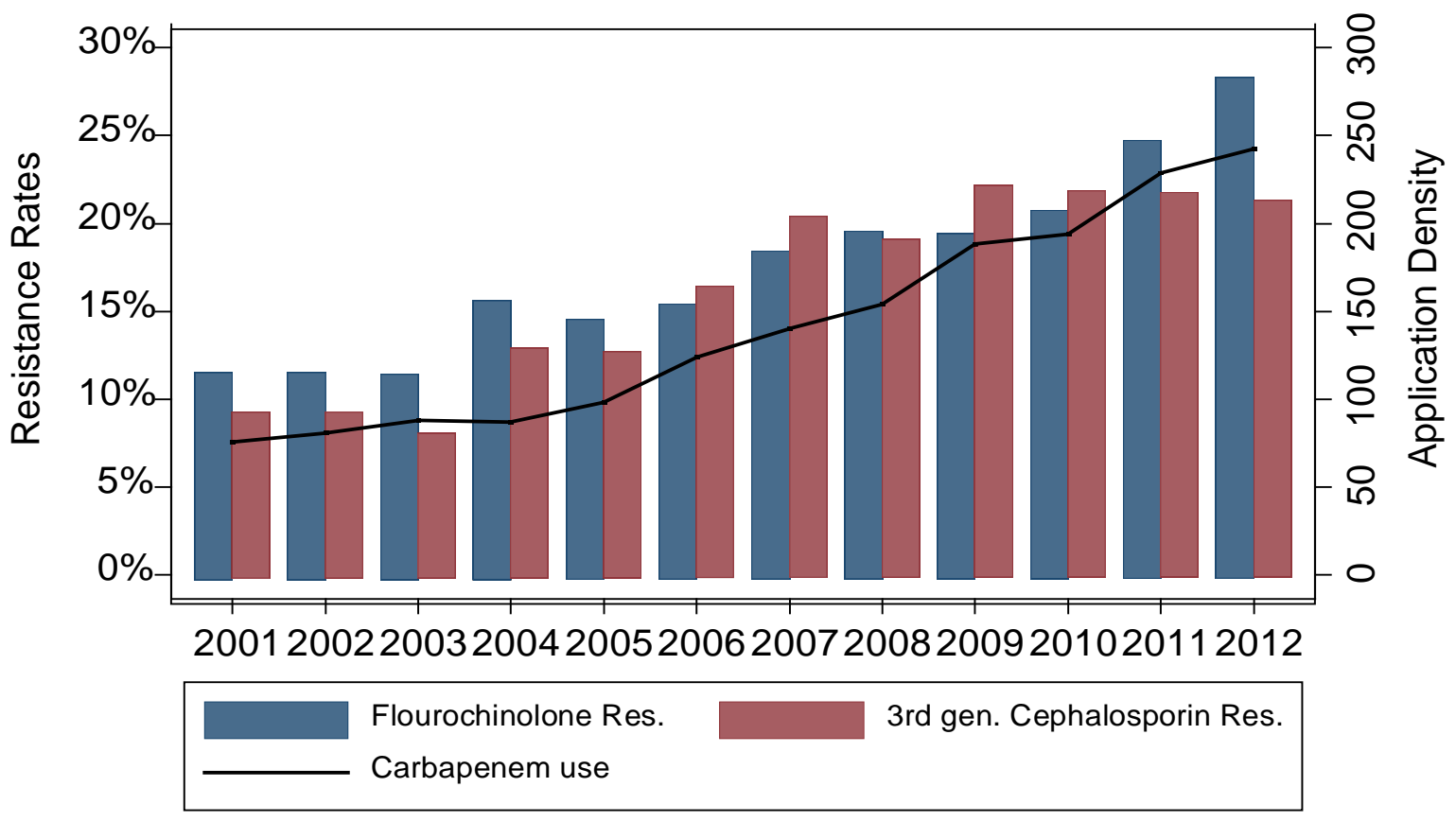

Note: Resistance Rate is the proportion of resistant isolates to all tested isolates. $R_{i}$ are pooled averages for all gram-negative pathogens tested for resistance against $t$ antibiotic class. Application densities are the yearly averages over all ICUs. It is defi as DDD per 1000 patient days.

Source:Own illustration adapted from Meyer(2013). 
Figure 3: Linezolid use and Vancomycin resistance in Enterococcus (VRE)

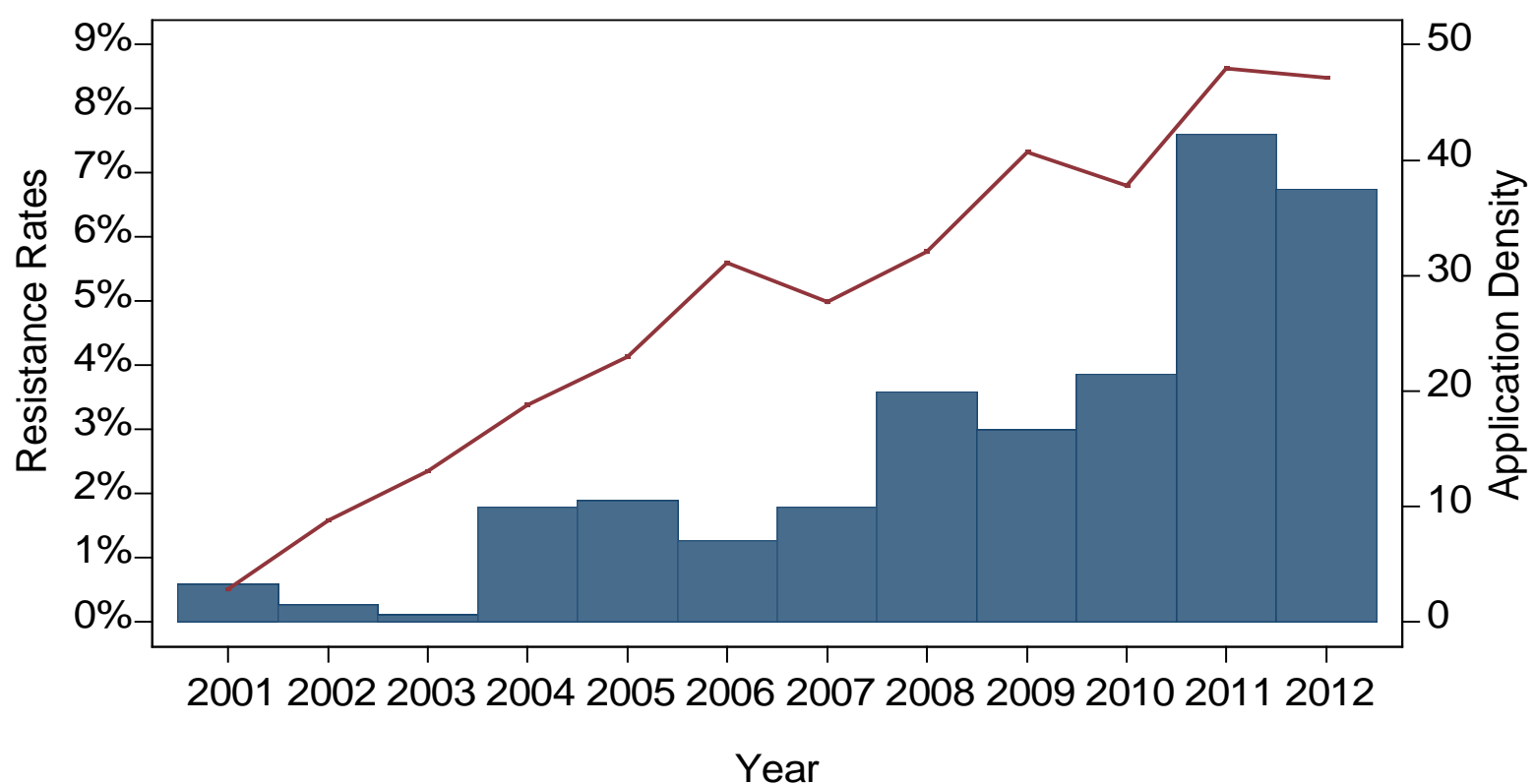

Vancomycin resistance in Enterococcus
Linezolid

Note: Resistance Rate is the proportion of resistant isolates to all tested isolates. Rates are pooled average for all gram-positive pathogens tested for resistance against glyopetides.

Figure 4: Resistance and Antibiotic application over time for an exemplary ICU for 24 months

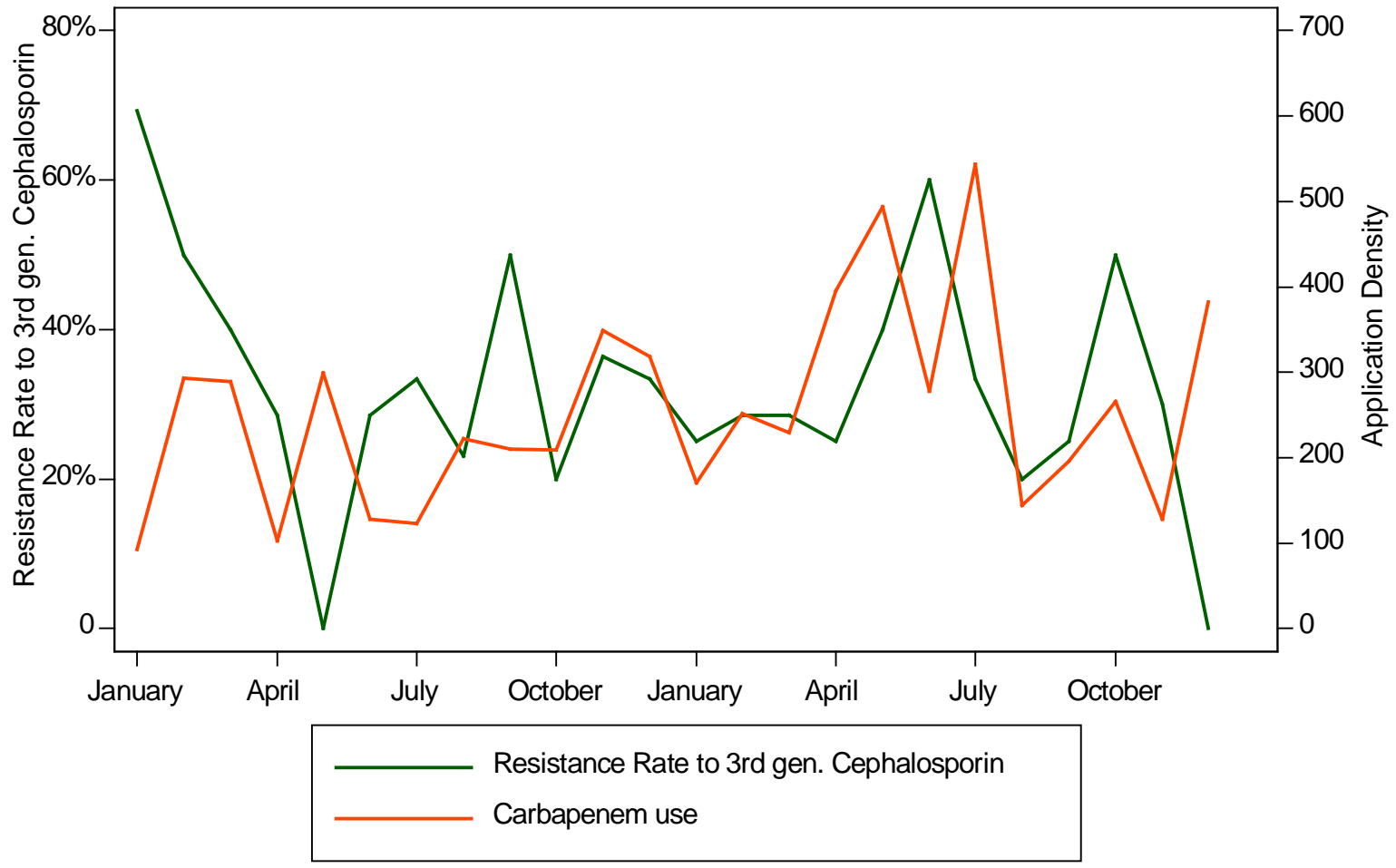

Note: This graph shows the correlation of carbapenem application and 3rd generation cephalosporin resistance in one ICU for a 24 month period in 2008-2009 
Table 1: Descriptive Panel Statistics

\begin{tabular}{|c|c|c|c|c|c|c|}
\hline Variable & Category & Mean & sd & $\min$ & $\max$ & obs \\
\hline Total Antibiotic Use AD & $\begin{array}{l}\text { overall } \\
\text { between } \\
\text { within }\end{array}$ & 1395,35 & $\begin{array}{l}604,69 \\
385,35 \\
482,74\end{array}$ & $\begin{array}{r}0,00 \\
718,16 \\
-501,53\end{array}$ & $\begin{array}{r}10079,20 \\
2653,78 \\
9577,67\end{array}$ & $\begin{array}{l}5506,00 \\
66,00 \\
83,42\end{array}$ \\
\hline Carbapanem use (AD) & $\begin{array}{l}\text { overall } \\
\text { between } \\
\text { within }\end{array}$ & 146,85 & $\begin{array}{r}140,21 \\
99,98 \\
107,07\end{array}$ & $\begin{array}{r}0,00 \\
7,79 \\
-264,78\end{array}$ & $\begin{array}{r}1726,36 \\
558,61 \\
1708,77\end{array}$ & $\begin{array}{l}5506,00 \\
66,00 \\
83,42\end{array}$ \\
\hline Glycopeptide use (AD) & $\begin{array}{l}\text { overall } \\
\text { between } \\
\text { within }\end{array}$ & 43,77 & $\begin{array}{l}64,01 \\
45,14 \\
53,90\end{array}$ & $\begin{array}{r}0,00 \\
3,78 \\
-102,24\end{array}$ & $\begin{array}{r}2168,92 \\
233,42 \\
2177,51\end{array}$ & $\begin{array}{l}5506,00 \\
66,00 \\
83,42\end{array}$ \\
\hline Linezolid use (AD) & $\begin{array}{l}\text { overall } \\
\text { between } \\
\text { within }\end{array}$ & 30,25 & $\begin{array}{l}47,06 \\
24,26 \\
40,61\end{array}$ & $\begin{array}{r}0,00 \\
0,60 \\
-82,76\end{array}$ & $\begin{array}{l}977,01 \\
130,19 \\
978,39\end{array}$ & $\begin{array}{l}5234,00 \\
66,00 \\
79,30\end{array}$ \\
\hline VRE (RR) & $\begin{array}{l}\text { overall } \\
\text { between } \\
\text { within }\end{array}$ & 0,03 & $\begin{array}{l}0,11 \\
0,05 \\
0,10\end{array}$ & $\begin{array}{r}0,00 \\
0,00 \\
-0.22\end{array}$ & $\begin{array}{l}1,00 \\
0,25 \\
1.01\end{array}$ & $\begin{array}{l}4779,00 \\
65,00 \\
73,52\end{array}$ \\
\hline $3^{\text {rd }}$ gen Cephalosporin Res. (RR) & $\begin{array}{l}\text { overall } \\
\text { between } \\
\text { within }\end{array}$ & 0,17 & $\begin{array}{l}0,18 \\
0,09 \\
0,16\end{array}$ & $\begin{array}{r}0,00 \\
0,04 \\
-0,30\end{array}$ & $\begin{array}{l}1,00 \\
0,47 \\
1,09\end{array}$ & $\begin{array}{l}5339,00 \\
66,00 \\
80,89\end{array}$ \\
\hline $\begin{array}{l}2^{\text {nd }} \text { and } 3^{\text {rd }} \text { gen. Fluorochinolone } \\
\text { Resistance (RR) }\end{array}$ & $\begin{array}{l}\text { overall } \\
\text { between } \\
\text { within }\end{array}$ & 0,18 & $\begin{array}{l}0,22 \\
0,11 \\
0,20\end{array}$ & $\begin{array}{r}0,00 \\
0,04 \\
-0,42\end{array}$ & $\begin{array}{l}2,00 \\
0,60 \\
2,04\end{array}$ & $\begin{array}{l}5311,00 \\
66,00 \\
80,47\end{array}$ \\
\hline $\begin{array}{l}\text { Resistance to } \\
\text { Piperacillin/Tazobactam (RR) }\end{array}$ & $\begin{array}{l}\text { overall } \\
\text { between } \\
\text { within }\end{array}$ & 0,18 & $\begin{array}{l}0,22 \\
0,11 \\
0,20\end{array}$ & $\begin{array}{r}0,00 \\
0,04 \\
-0,42\end{array}$ & $\begin{array}{l}2,00 \\
0,60 \\
2,04\end{array}$ & $\begin{array}{l}5311,00 \\
66,00 \\
80,47\end{array}$ \\
\hline MRSA (RR) & $\begin{array}{l}\text { overall } \\
\text { between } \\
\text { within }\end{array}$ & 0,18 & $\begin{array}{l}0,20 \\
0,11 \\
0,18\end{array}$ & $\begin{array}{r}0,00 \\
0,06 \\
-0,22\end{array}$ & $\begin{array}{l}1,00 \\
0,50 \\
1,12\end{array}$ & $\begin{array}{l}4925,00 \\
66,00 \\
74,62\end{array}$ \\
\hline CNS incidence & $\begin{array}{l}\text { overall } \\
\text { between } \\
\text { within }\end{array}$ & 0,26 & $\begin{array}{l}0,28 \\
0,12 \\
0,26\end{array}$ & $\begin{array}{r}0,00 \\
0,05 \\
-0,25\end{array}$ & $\begin{array}{l}1,00 \\
0,51 \\
1,13\end{array}$ & $\begin{array}{l}5054,00 \\
66,00 \\
76,58\end{array}$ \\
\hline
\end{tabular}


Table 2: Resistance elasticity of carbapenem use

\begin{tabular}{|c|c|c|c|c|c|c|}
\hline \multirow{2}{*}{$\begin{array}{l}\text { Dependent Variable } \\
\text { Carbapenem AD (log) }\end{array}$} & \multicolumn{6}{|c|}{ Unit Fixed Effects } \\
\hline & 1 & 2 & 3 & 4 & 5 & 6 \\
\hline $\begin{array}{l}\text { Resistance to 3rd gen. } \\
\text { Cephalosporin }\end{array}$ & $\begin{array}{c}0.430 * * * \\
{[0.173-0.686]}\end{array}$ & $\begin{array}{c}0.428^{* * *} \\
{[0.164-0.692]}\end{array}$ & $\begin{array}{c}0.117 \\
{[-0.138-0.372]}\end{array}$ & $\begin{array}{c}0.080 \\
{[-0.182-0.343]}\end{array}$ & $\begin{array}{c}0.160 \\
{[-0.091-0.411]}\end{array}$ & $\begin{array}{c}0.137 \\
{[-0.122-0.395]}\end{array}$ \\
\hline$(t-1)$ & & $\begin{array}{c}0.237^{*} \\
{[-0.030-0.504]}\end{array}$ & & $\begin{array}{c}-0.116 \\
{[-0.381-0.150]}\end{array}$ & & $\begin{array}{c}-0.074 \\
{[-0.335-0.187]}\end{array}$ \\
\hline $\begin{array}{l}\text { Joint Significance of both } \\
\text { periods ( } p \text {-value) }\end{array}$ & & 0.002 & & 0.558 & & 0.483 \\
\hline $\begin{array}{l}\text { Resistance to } 2 \text { nd and } \\
3 \text { rd gen. Fluoroquinolones }\end{array}$ & $\begin{array}{c}0.128 \\
{[-0.053-0.309]}\end{array}$ & $\begin{array}{c}0.192^{*} \\
{[-0.007-0.390]}\end{array}$ & $\begin{array}{c}0.103 \\
{[-0.075-0.281]}\end{array}$ & $\begin{array}{c}0.112 \\
{[-0.083-0.306]}\end{array}$ & $\begin{array}{c}0.063 \\
{[-0.115-0.240]}\end{array}$ & $\begin{array}{c}0.090 \\
{[-0.103-0.283]}\end{array}$ \\
\hline$(\mathrm{t}-1)$ & & $\begin{array}{c}0.023 \\
{[-0.176-0.222]}\end{array}$ & & $\begin{array}{c}-0.084 \\
{[-0.278-0.110]}\end{array}$ & & $\begin{array}{c}-0.081 \\
{[-0.274-0.112]}\end{array}$ \\
\hline $\begin{array}{l}\text { Joint Significance of both } \\
\text { periods ( } p \text {-value) }\end{array}$ & & 0.163 & & 0.292 & & 0.391 \\
\hline $\begin{array}{l}\text { Resistance to Piperacilin/ } \\
\text { Tazobactam }\end{array}$ & $\begin{array}{c}0.193 * \\
{[-0.016-0.402]}\end{array}$ & $\begin{array}{c}0.304^{* * *} \\
{[0.084-0.525]}\end{array}$ & $\begin{array}{c}0.086 \\
{[-0.119-0.291]}\end{array}$ & $\begin{array}{c}0.133 \\
{[-0.084-0.350]}\end{array}$ & $\begin{array}{c}0.117 \\
{[-0.087-0.320]}\end{array}$ & $\begin{array}{c}0.185 * \\
{[-0.029-0.399]}\end{array}$ \\
\hline$(t-1)$ & & $\begin{array}{c}0.149 \\
{[-0.074-0.372]}\end{array}$ & & $\begin{array}{c}0.059 \\
{[-0.160-0.278]}\end{array}$ & & $\begin{array}{c}0.064 \\
{[-0.152-0.280]}\end{array}$ \\
\hline $\begin{array}{l}\text { Joint Significance of both } \\
\text { periods ( } p \text {-value) }\end{array}$ & & 0.017 & & 0.450 & & 0.219 \\
\hline Trend Variable & & & & & $\begin{array}{c}0.012 * * * \\
{[0.011-0.013]}\end{array}$ & $\begin{array}{c}0.011^{* * *} \\
{[0.010-0.013]}\end{array}$ \\
\hline Constant & $\begin{array}{c}4.257^{* * *} \\
{[4.211-4.303]}\end{array}$ & $\begin{array}{c}4.179 * * * \\
{[4.117-4.241]}\end{array}$ & $\begin{array}{c}0.258 \\
{[-0.416-0.931]}\end{array}$ & $\begin{array}{c}0.979 * * * \\
{[0.333-1.626]}\end{array}$ & $\begin{array}{c}3.398^{* * *} \\
{[3.313-3.482]}\end{array}$ & $\begin{array}{c}3.452^{* * *} \\
{[3.362-3.543]}\end{array}$ \\
\hline $\begin{array}{l}\text { Joint Significance of all } \\
\text { independent Variables ( } p \text { - } \\
\text { value) }\end{array}$ & 0.000 & 0.000 & 0.159 & 0.164 & 0.000 & 0.088 \\
\hline Time Fixed Effects & No & No & Yes & Yes & No & No \\
\hline$N$ & 4,792 & 4,503 & 4,792 & 4,503 & 4,792 & 4,503 \\
\hline$R^{2}$ & 0.01 & 0.01 & 0.11 & 0.11 & 0.07 & 0.06 \\
\hline
\end{tabular}

Notes: The regressions include monthly data on the application density (AD) of carbapenems (Imipenem, meropenem, ertapenem and doripenem) from 2001 - 2012. Resistance is measured as the resistance rate: resistant isolates as a proportion of all tested isolates. All included resistance rate are for gram-negative pathogens only. The $95 \%$ confidence intervals are given in brackets.

*** Significant at the 1 percent level.

** Significant at the 5 percent level.

* Significant at the 10 percent level. 
Table 3. Resistance elasticity of linezolid use

\begin{tabular}{|c|c|c|c|c|c|c|}
\hline \multirow{2}{*}{$\begin{array}{l}\text { Dependent Variable: } \\
\text { Linezolid AD(log) }\end{array}$} & \multicolumn{6}{|c|}{ Unit Fixed Effects } \\
\hline & 1 & 2 & 3 & 4 & 5 & 6 \\
\hline MRSA & $\begin{array}{c}0.637 * * * \\
{[0.447-0.826]}\end{array}$ & $\begin{array}{c}0.720 * * * \\
{[0.509-0.930]}\end{array}$ & $\begin{array}{c}0.539 * * * \\
{[0.352-0.725]}\end{array}$ & $\begin{array}{c}0.597 * * * \\
{[0.393-0.802]}\end{array}$ & $\begin{array}{c}0.602 * * * \\
{[0.418-0.787]}\end{array}$ & $\begin{array}{c}0.687^{* * *} \\
{[0.484-0.889]}\end{array}$ \\
\hline$(t-1)$ & & $\begin{array}{c}0.214^{* *} \\
{[0.005-0.423]}\end{array}$ & & $\begin{array}{c}0.147 \\
{[-0.056-0.350]}\end{array}$ & & $\begin{array}{c}0.173^{*} \\
{[-0.028-0.374]}\end{array}$ \\
\hline $\begin{array}{l}\text { Joint Significance of both } \\
\text { periods ( } p \text {-value) }\end{array}$ & & 0.000 & & 0.000 & & 0.000 \\
\hline VRE & $\begin{array}{c}1.159 * * * \\
{[0.707-1.612]}\end{array}$ & $\begin{array}{c}1.580 * * * \\
{[1.080-2.080]}\end{array}$ & $\begin{array}{c}0.771 * * * \\
{[0.320-1.223]}\end{array}$ & $\begin{array}{c}0.859 * * * \\
{[0.363-1.354]}\end{array}$ & $\begin{array}{c}0.747^{* * *} \\
{[0.301-1.193]}\end{array}$ & $\begin{array}{c}0.852 * * * \\
{[0.362-1.342]}\end{array}$ \\
\hline$(t-1)$ & & $\begin{array}{c}1.346^{* * *} \\
{[0.857-1.835]}\end{array}$ & & $\begin{array}{c}0.622 * * \\
{[0.138-1.107]}\end{array}$ & & $\begin{array}{c}0.654 * * * \\
{[0.175-1.132]}\end{array}$ \\
\hline $\begin{array}{l}\text { Joint Significance of both } \\
\text { periods ( } p \text {-value) }\end{array}$ & & 0.000 & & 0.000 & & 0.001 \\
\hline Trend Variable & & & & & $\begin{array}{c}0.019 * * * \\
{[0.017-0.021]}\end{array}$ & $\begin{array}{c}0.018^{* * *} \\
{[0.016-0.020]}\end{array}$ \\
\hline Constant & $\begin{array}{c}2.030 * * * \\
{[1.971-2.088]}\end{array}$ & $\begin{array}{c}1.947 * * * \\
{[1.870-2.025]}\end{array}$ & $\begin{array}{c}0.639 * \\
{[-0.008-1.287]}\end{array}$ & $\begin{array}{c}0.786^{* *} \\
{[0.110-1.463]}\end{array}$ & $\begin{array}{c}0.491 * * * \\
{[0.362-0.620]}\end{array}$ & $\begin{array}{c}0.482 * * * \\
{[0.337-0.627]}\end{array}$ \\
\hline $\begin{array}{l}\text { Joint Significance of all in- } \\
\text { dependent Variables ( } p \text {-value) }\end{array}$ & 0.000 & 0.000 & 0.000 & 0.000 & 0.000 & 0.000 \\
\hline Time Fixed Effects & No & No & Yes & Yes & No & No \\
\hline$N$ & 4,224 & 3,755 & 4,224 & 3,755 & 4,224 & 3,755 \\
\hline$R^{2}$ & 0.02 & 0.03 & 0.14 & 0.16 & 0.09 & 0.10 \\
\hline
\end{tabular}

Notes: The regression includes monthly data on the application density (AD) of Linezolid from $2001-2012$. MRSA rates gives the proportion of tested S.aureus isolates that are resistant to oxacillin. VRE rates gives the proportion of tested Enterococcus isolates that are resistant to vancomycin. Resistance is measured as the resistance rate: resistant isolates as a proportion of all tested isolates. The $95 \%$ confidence intervals are given in brackets.

*** Significant at the 1 percent level.

** Significant at the 5 percent level.

* Significant at the 10 percent level. 
Table 4: Resistance elasticity of glycopeptide use

\begin{tabular}{|c|c|c|c|c|c|c|}
\hline \multirow{2}{*}{$\begin{array}{l}\text { Dependent Variable: } \\
\text { Glycopeptide AD (log) }\end{array}$} & \multirow[b]{2}{*}{1} & \multirow[b]{2}{*}{2} & \multirow[b]{2}{*}{3} & \multirow[b]{2}{*}{4} & \multirow[b]{2}{*}{5} & \multirow[b]{2}{*}{6} \\
\hline & & & & & & \\
\hline MRSA & $\begin{array}{c}0.379 * * * \\
{[0.195-0.563]}\end{array}$ & $\begin{array}{c}0.492 * * * \\
{[0.290-0.694]}\end{array}$ & $\begin{array}{c}0.371^{* * *} \\
{[0.184-0.557]}\end{array}$ & $\begin{array}{c}0.509 * * * \\
{[0.304-0.714]}\end{array}$ & $\begin{array}{c}0.372 * * * \\
{[0.189-0.555]}\end{array}$ & $\begin{array}{c}0.486 * * * \\
{[0.285-0.687]}\end{array}$ \\
\hline$(\mathrm{t}-1)$ & & $\begin{array}{c}0.171 \\
{[-0.033-0.374]}\end{array}$ & & $\begin{array}{c}0.093 \\
{[-0.114-0.299]}\end{array}$ & & $\begin{array}{c}0.168 \\
{[-0.034-0.370]}\end{array}$ \\
\hline $\begin{array}{l}\text { Joint Significance of both } \\
\text { periods ( } p \text {-value) }\end{array}$ & & 0.000 & & 0.000 & & 0.000 \\
\hline CNS & $\begin{array}{c}0.226 * * * \\
{[0.145-0.306]}\end{array}$ & $\begin{array}{c}0.241 * * * \\
{[0.154-0.328]}\end{array}$ & $\begin{array}{c}0.222^{* * *} \\
{[0.140-0.304]}\end{array}$ & $\begin{array}{c}0.228 * * * \\
{[0.140-0.316]}\end{array}$ & $\begin{array}{c}0.237 * * * \\
{[0.157-0.318]}\end{array}$ & $\begin{array}{c}0.248 * * * \\
{[0.161-0.334]}\end{array}$ \\
\hline$(\mathrm{t}-1)$ & & $\begin{array}{c}0.113^{* *} \\
{[0.026-0.200]}\end{array}$ & & $\begin{array}{c}0.109 * * \\
{[0.021-0.197]}\end{array}$ & & $\begin{array}{c}0.120 * * * \\
{[0.034-0.207]}\end{array}$ \\
\hline $\begin{array}{l}\text { Joint Significance of both } \\
\text { periods ( } p \text {-value) }\end{array}$ & & 0.000 & & 0.000 & & 0.000 \\
\hline Trend Variable & & & & & $\begin{array}{c}0.006 * * * \\
{[0.004-0.008]}\end{array}$ & $\begin{array}{c}0.007^{* * *} \\
{[0.005-0.009]}\end{array}$ \\
\hline Constant & $\begin{array}{c}2.510 * * * \\
{[2.415-2.605]}\end{array}$ & $\begin{array}{c}2.233 * * * \\
{[2.084-2.382]}\end{array}$ & $\begin{array}{c}-0.151 \\
{[-0.664-0.362]}\end{array}$ & $\begin{array}{c}-0.727^{* * *} \\
{[-1.236--0.218]}\end{array}$ & $\begin{array}{c}2.044^{* * *} \\
{[1.905-2.183]}\end{array}$ & $\begin{array}{c}1.702 * * * \\
{[1.517-1.887]}\end{array}$ \\
\hline $\begin{array}{l}\text { Joint Significance of all in- } \\
\text { dependent Variables. ( } p \text {-value) }\end{array}$ & 0.000 & 0.000 & 0.000 & 0.000 & 0.000 & 0.000 \\
\hline Time Fixed Effects & No & No & Yes & Yes & No & No \\
\hline$N$ & 4,130 & 3,553 & 4,130 & 3,553 & 4,130 & 3,553 \\
\hline$R^{2}$ & 0.01 & 0.02 & 0.06 & 0.08 & 0.02 & 0.03 \\
\hline
\end{tabular}


Appendix

Table A1. Panel Structure

statid: $1,3, \ldots, 72 \quad n=66$

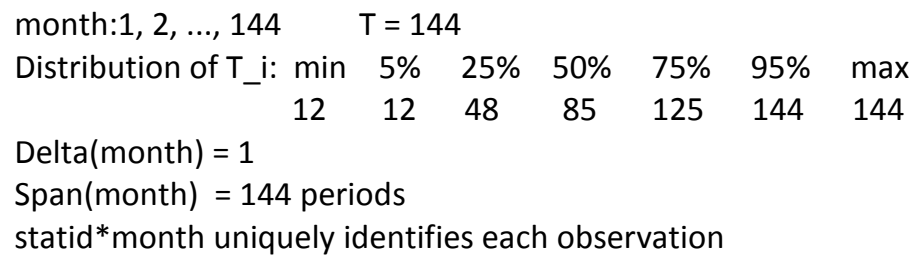

Freq. Percent Cum. | Pattern

$11 \quad 16.6716 .67 \mid 111111111111111111111111111111111111111111111111111111111111111111111111111111111111111111111111111111111111111111111111111111111111111111111111$

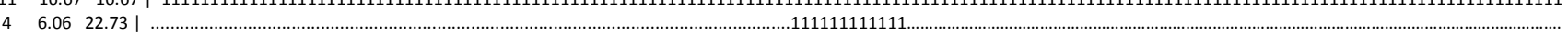

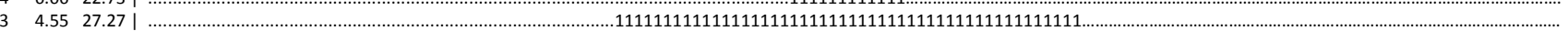

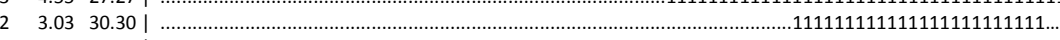

2 2 3.03 33.33 |

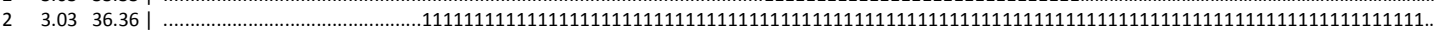

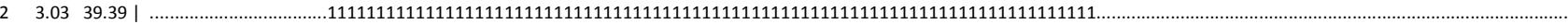

$2 \quad 3.03 \quad 42.42 \mid \ldots \ldots \ldots \ldots \ldots \ldots \ldots . .111111111111111111111111111111111111111111111111111111111111111111111111111111111111111111111111111111111111111111111111$

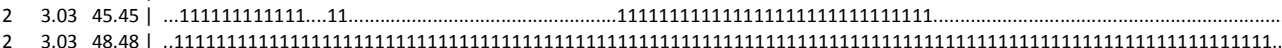

$2 \quad 3.0351 .52 \mid 111111111111111111111111111111111111111111111111111111111111111111 . .1111111111111111111111111111111111111111111111111111111111111111111111111111 .$.

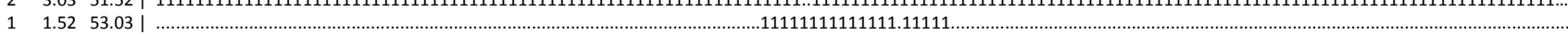

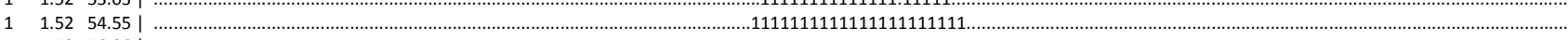

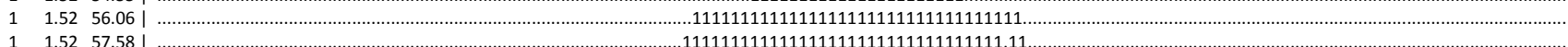

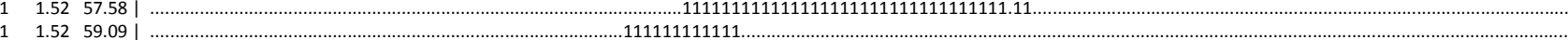

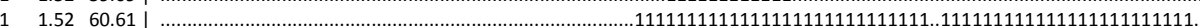

$\begin{array}{lll}1.52 & 62.12 \mid & 0\end{array}$

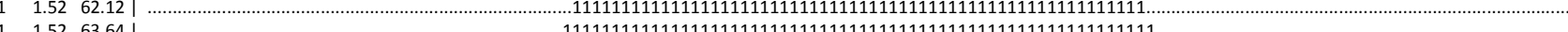

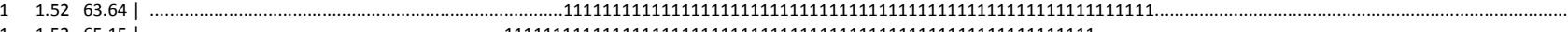

1101.52 65.15

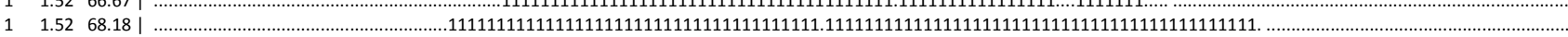

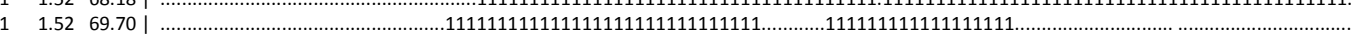

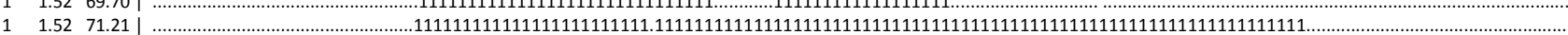

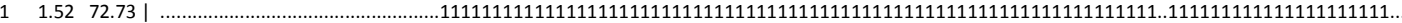

$1 \quad 1.52 \quad 74.24 \mid \ldots \ldots \ldots \ldots \ldots \ldots \ldots \ldots . .111111111111111111111111111111111111111111111111111111111111111111111111111111111111111111111111111111111111111111111$

$1 \quad 1.52 \quad 75.76 \mid-. . .111111111111111111111111111111111111111111111 .$.

\begin{tabular}{llll|lll}
1 & 1.52 & 77.27 & $1111111111111111111111111111111111111111111 \quad 111111111111111111111111111111$ & 111111111111111111
\end{tabular}

$1 \quad 1.52 \quad 78.79 \mid \ldots . . .11111111111111111111111111111111111111111111111111111111111111111111111$

$1 \quad 1.5280 .30 \mid . .111111111111111111111 .11 \ldots 111111111111111111111.111111111111111111111111 .11111111111$

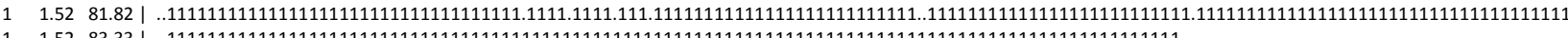

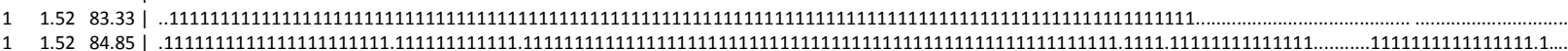

$1 \quad 1.5286 .36 \mid .1111111111111111111111111111111 \ldots \ldots .1 .111111111111111 \ldots . .111111111111111111 \ldots \ldots \ldots$

$1 \quad 1.5287 .88 \mid .11111111111111111111111111111111111111111111111111111111111111111111111111111111111111111111111$

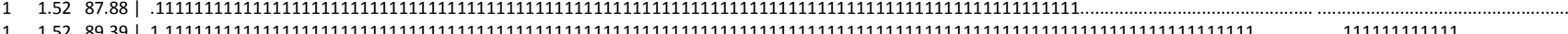

$1 \quad 1.52$ 8..39

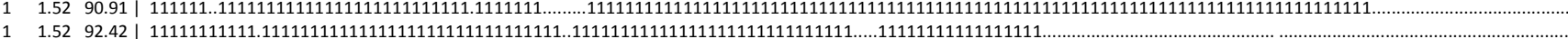

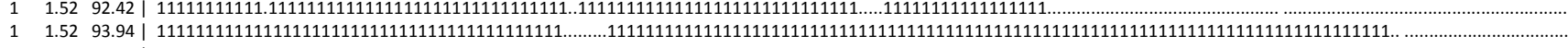

$1 \quad 1.52$ 95.45| 11111111111111111111111111111111111111111111111111111111.111111111.

$1 \quad 1.5296 .97 \mid 111111111111111111111111111111111111111111111111111111111111$

$1 \quad 1.5298 .48$ | 111111111111111111111111111111111111111111111111111111111111111111111111111111111111111

$1 \quad 1.52100 .00 \mid 11111111111111111111111111111111111111111111111111111111111111111111111111111111111111111111111111111111111111111111111111111111111111.111111111 . .$.

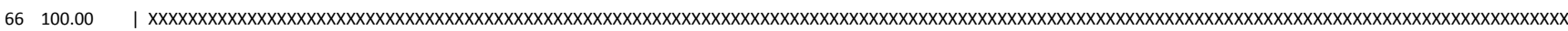


Table A2. Pathogens with collected Resistance Rates

\begin{tabular}{|c|c|}
\hline Pathogen & Antibiotics \\
\hline S. aureus & $\begin{array}{l}\text { Oxacillin, Vancomycin, Teicoplanin, Ciprofloxacin, } \\
\text { Linezolid, Tigecyclin, Daptomycin }\end{array}$ \\
\hline S. pneumoniae & $\begin{array}{l}\text { Penicillin, Cefotaxim or Ceftazidim or } \\
\text { Ceftriaxon,Vancomycin, Erythromycin, Ciprofloxacin, } \\
\text { Moxifloxacin, Levofloxacin }\end{array}$ \\
\hline CNS & Cefoxitin, Vancomycin, Teicoplanin, Tigecyclin \\
\hline E. faecalis & $\begin{array}{l}\text { Ampicillin, Vancomycin, Teicoplanin, Ciprofloxacin, } \\
\text { Levofloxacin, Moxifloxacin, Tigecyclin, Daptomycin }\end{array}$ \\
\hline E. faecium & $\begin{array}{l}\text { Ampicillin, Vancomycin, Teicoplanin, Ciprofloxacin, } \\
\text { Linzolid, Tigecyclin, Daptomycin }\end{array}$ \\
\hline $\begin{array}{l}\text { E. coli } \\
\text { K. Pneunomia }\end{array}$ & $\begin{array}{l}\text { Cefotaxim oder Ceftazidim or Ceftriaxon, Cefuroxim or } \\
\text { Cefotiam, Imipenem, Meropenem, Gentamicin, } \\
\text { Tobramycin, Amikacin, Piperacillin/ } \\
\text { Betalactamaseinhibitor, Ampicillin/ Sulbactam, } \\
\text { Amoxicillin/ Clavulansäure, Ciprofloxacin, Levofloxacin, } \\
\text { Tigecyclin }\end{array}$ \\
\hline $\begin{array}{l}\text { E. cloacae } \\
\text { S. marcescens }\end{array}$ & $\begin{array}{l}\text { Cefotaxim or Ceftazidim or Ceftriaxon, Imipenem, } \\
\text { Meropenem, Amikacin, Ciprofloxacin, Levofloxacin, } \\
\text { Tigecyclin }\end{array}$ \\
\hline Citrobacter & $\begin{array}{l}\text { Imipenem, Meropenem, Amikacin, Ciprofloxacin, } \\
\text { Levofloxacin, Tigecyclin }\end{array}$ \\
\hline P. aeruginosa & $\begin{array}{l}\text { Ceftazidim, Piperacillin/Tazobactam, Imipenem, } \\
\text { Meropenem, Gentamicin, Tobramycin, Amikacin, } \\
\text { Ciprofloxacin, Levofloxacin, Tigecyclin }\end{array}$ \\
\hline A. baumannii & $\begin{array}{l}\text { Ceftazidim, Cefuroxim or Cefotiam, } \\
\text { Piperacillin/Sulbactam, Piperacillin/Tazobactam, } \\
\text { Imipenem, Meropenem, Amikacin, Ciprofloxacin, } \\
\text { Levofloxacin, Tigecyclin }\end{array}$ \\
\hline
\end{tabular}


Table A3. Dependent Variable Autocorrelation

\begin{tabular}{l|ll} 
Correlation & Carbapanem use & Carbapenem use $(\mathrm{t}-1)$ \\
\hline Carbapanem use & 1 & 1 \\
Carbapenem use (t-1) & 0.6747 & Linezolid use (t-1) \\
Correlation & Linezolid use & \\
\hline Linezolid use & 1 & 1 \\
Linezolid use (t-1) & 0.4327 & Glycopeptide use (t-1) \\
Correlation & Glycopeptide use & \\
\hline Glycopeptide use & 1 & 1
\end{tabular}


Table A4. Panel Unit Root Tests

Choi's (2001) combined p-value ADF fisher test

$\mathrm{HO}$ : All panels contain a unit root $\mathrm{H} 1$ : At least one panel is stationary

\begin{tabular}{|c|c|c|c|c|}
\hline Variable & category & Statistic & pValue & obs \\
\hline \multirow[t]{4}{*}{ Carbapenems (AD) } & Inverse chi-squared & 1023,016541 & 0,000 & 5506 \\
\hline & Inverse normal Z statistic & $-24,728317$ & 0,000 & \\
\hline & Inverse logit L statistic & $-34,536419$ & 0,000 & \\
\hline & modified inverse chi-squared P_m & 54,838276 & 0,000 & \\
\hline \multirow[t]{4}{*}{ Glycopeptides (AD) } & Inverse chi-squared & 1471,94873 & 0,000 & 5506 \\
\hline & Inverse normal Z statistic & $-30,890514$ & 0,000 & \\
\hline & Inverse logit L statistic & $-49,6152$ & 0,000 & \\
\hline & modified inverse chi-squared P_m & 82,468147 & 0,000 & \\
\hline \multirow[t]{4}{*}{ Linezolid (AD) } & Inverse chi-squared & 1420,76355 & 0,000 & 5234 \\
\hline & Inverse normal Z statistic & $-30,501421$ & 0,000 & \\
\hline & Inverse logit L statistic & $-48,094536$ & 0,000 & \\
\hline & modified inverse chi-squared P_m & 79,317917 & 0,000 & \\
\hline \multirow[t]{4}{*}{ Glycopeptide resistance (RR) } & Inverse chi-squared & 1345,41333 & 0,000 & 5352 \\
\hline & Inverse normal Z statistic & $-30,074745$ & 0,000 & \\
\hline & Inverse logit L statistic & $-49,991863$ & 0,000 & \\
\hline & modified inverse chi-squared P_m & 74,680428 & 0,000 & \\
\hline \multirow[t]{4}{*}{ 3rd gen Cephalosporin resistance (RR) } & Inverse chi-squared & 1304,213745 & 0,000 & 5339 \\
\hline & Inverse normal Z statistic & $-28,361797$ & 0,000 & \\
\hline & Inverse logit L statistic & $-44,049156$ & 0,000 & \\
\hline & modified inverse chi-squared P_m & 72,144768 & 0,000 & \\
\hline \multirow[t]{4}{*}{ Fluoroquinolone resistance (RR) } & Inverse chi-squared & 1574,672119 & 0,000 & 5311 \\
\hline & Inverse normal Z statistic & $-32,429245$ & 0,000 & \\
\hline & Inverse logit L statistic & $-53,696133$ & 0,000 & \\
\hline & modified inverse chi-squared $P_{-} m$ & 88,790329 & 0,000 & \\
\hline \multirow[t]{4}{*}{ Carbapenem resistance (RR) } & Inverse chi-squared & 1326,415771 & 0,000 & 4801 \\
\hline & Inverse normal Z statistic & $-28,845137$ & 0,000 & \\
\hline & Inverse logit L statistic & $-46,823093$ & 0,000 & \\
\hline & modified inverse chi-squared P_m & 74,900986 & 0,000 & \\
\hline \multirow[t]{4}{*}{ Resistance to Piperacilin/tazobactam (RR) } & Inverse chi-squared & 1255,326416 & 0,000 & 4925 \\
\hline & Inverse normal Z statistic & $-28,137737$ & 0,000 & \\
\hline & Inverse logit L statistic & $-44,073948$ & 0,000 & \\
\hline & modified inverse chi-squared $P_{-} m$ & 70,457901 & 0,000 & \\
\hline \multirow[t]{4}{*}{ MRSA (RR) } & Inverse chi-squared & 1292,069214 & 0,000 & 5054 \\
\hline & Inverse normal Z statistic & $-27,235807$ & 0,000 & \\
\hline & Inverse logit L statistic & $-43,029205$ & 0,000 & \\
\hline & modified inverse chi-squared $P_{-} \mathrm{m}$ & 72,068474 & 0,000 & \\
\hline \multirow[t]{4}{*}{ Incidence of CNS } & Inverse chi-squared & 1279,568604 & 0,000 & 5506 \\
\hline & Inverse normal Z statistic & $-27,502605$ & 0,000 & \\
\hline & Inverse logit L statistic & $-43,448814$ & 0,000 & \\
\hline & modified inverse chi-squared P_m & 70,62796 & 0,000 & \\
\hline \multirow[t]{4}{*}{ Vancomycin resistance in Enterococcus (RR) } & Inverse chi-squared & 1407,782715 & 0,000 & 4779 \\
\hline & Inverse normal Z statistic & $-30,768436$ & 0,000 & \\
\hline & Inverse logit L statistic & $-54,028957$ & 0,000 & \\
\hline & modified inverse chi-squared P_m & 82,313805 & 0,000 & \\
\hline
\end{tabular}


Table A5. Tobit fixed effects estimation for resistance elasticity of linezolid use

\begin{tabular}{|c|c|c|c|}
\hline \multirow{2}{*}{$\begin{array}{l}\text { Dependent Variable } \\
\text { Linezolid AD }\end{array}$} & \multicolumn{3}{|c|}{ Tobit Fixed-Effects Estimation } \\
\hline & 1 & $A P E$ & 2 \\
\hline \multirow[t]{2}{*}{ MRSA } & $1.046 * * *$ & $0.689 * * *$ & $1.062 * * *$ \\
\hline & $(0.652-1.439)$ & $(0.469-0.911)$ & $(0.652-1.472)$ \\
\hline \multirow[t]{2}{*}{ VRE } & $3.239 * * *$ & $2.137 * * *$ & $2.669 * * *$ \\
\hline & $(2.285-4.193)$ & $(1.632-2.640)$ & $(1.965-3.373)$ \\
\hline Joint Significance of all independent variables ( $p$-value) & 0.000 & 0.000 & 0.000 \\
\hline$N$ & 4,289 & 4,289 & 4,289 \\
\hline $\mathrm{R}^{2}$ & 0.09 & & \\
\hline Log-Likelihood & $-7,173.06$ & & \\
\hline \multicolumn{4}{|c|}{$\begin{array}{l}\text { Notes: The regressions use monthly data on the application density (AD) of Linezolid from } 2001-2012 \text {. MRSA rates gives } \\
\text { the proportion of tested S.aureus isolates that are resistant to Oxacillin. VRE rates gives the proportion of tested } \\
\text { Enterococcus isolates that are resistant to Vancomycin. Column } 1 \text { gives the results of a Tobit regression using dummy } \\
\text { variables for each unit. APE gives the Average Partial effects of that estimation. Column } 2 \text { presents the results of Tobit } \\
\text { fixed effect estimator developed by Honoré (1992). The implementation of this estimator is limited in its possible } \\
\text { specifications and calculated results so that no partial effects or R-squared were estimated. P-values for the joint } \\
\text { significance of independent variables were calculated using Wald tests. } H_{0} \text { is that the variables do not have an effect. } \\
\text { *** Significant at the } 1 \text { percent level. }\end{array}$} \\
\hline
\end{tabular}


Table A6. Tobit fixed effect estimation for resistance elasticity of glycopeptide use

\begin{tabular}{|c|c|c|c|}
\hline \multirow{2}{*}{$\begin{array}{l}\text { Dependent Variable } \\
\text { Glycopeptide AD (log) }\end{array}$} & \multicolumn{3}{|c|}{ Tobit Fixed-Effects Estimation } \\
\hline & 1 & APE & 2 \\
\hline MRSA & $\begin{array}{c}0.476 * * * \\
(0.031-0.922)\end{array}$ & $\begin{array}{c}0.416 * * * \\
(0.030-0.802)\end{array}$ & $\begin{array}{c}0.477^{* * *} \\
(0.135-0.818)\end{array}$ \\
\hline Incidence of CNS (log) & $\begin{array}{c}0.282 * * * \\
(0.113-0.434)\end{array}$ & $\begin{array}{c}0.239 * * * \\
(0.103-0.376)\end{array}$ & $\begin{array}{c}0.269 * * * \\
(0.129-0.409)\end{array}$ \\
\hline Joint Significance of all independent variables ( $p$-value) & 0.000 & 0.000 & 0.000 \\
\hline$N$ & 4,195 & 4,195 & 4,195 \\
\hline $\mathrm{R}^{2}$ & 0.08 & & \\
\hline Log-Likelihood & $-9,231.53$ & & \\
\hline \multicolumn{4}{|c|}{$\begin{array}{l}\text { Notes: The sample use monthly data on the application density (AD) of Glycopetides (Vancomycin and Teicoplanin) from } \\
2001-2012 \text {. MRSA rates gives the proportion of tested S.aureus isolates that are resistant to Oxacillin. CNS is the } \\
\text { incidence of coagulase-negative staphylococcus as measure in tested isolates. Column } 1 \text { gives the results of a Tobit } \\
\text { regression using dummy variables for each unit. APE gives the Average Partial effects of that estimation. Column } 2 \\
\text { presents the results of Tobit fixed effect estimator developed by Honoré (1992). The implementation of this estimator is } \\
\text { limited in its possible specifications and calculated results so that no partial effects or R-squared could be estimated and } \\
\text { no standard-error clustering could be performed. } 95 \% \text { confidence intervals are given in brackets. P-values for the joint } \\
\text { significance of independent variables were calculated using Wald tests. } H_{0} \text { is that the variables do not have an effect. } \\
* * * \text { Significant at the } 1 \text { percent level. } \\
\text { ** Significant at the } 5 \text { percent level. } \\
* \text { Significant at the } 10 \text { percent level. }\end{array}$} \\
\hline
\end{tabular}


Table A7. Resistance Elasticity of Carbapenems (Resistance Density)

\begin{tabular}{|c|c|c|c|c|c|c|}
\hline \multirow{2}{*}{$\begin{array}{l}\text { Dependent Variable } \\
\text { Carbapenem AD (log) }\end{array}$} & \multicolumn{6}{|c|}{ Unit Fixed Effects } \\
\hline & 1 & 2 & 3 & 4 & 5 & 6 \\
\hline Resistance to 3rd gen. & $0.174^{* * *}$ & $0.166^{* * *}$ & 0.064 & 0.057 & $0.081 * *$ & $0.072 *$ \\
\hline Cephalosporin & {$[0.096-0.251]$} & {$[0.087-0.246]$} & {$[-0.014-0.141]$} & {$[-0.022-0.136]$} & {$[0.005-0.157]$} & {$[-0.006-0.150]$} \\
\hline \multirow[t]{2}{*}{$(t-1)$} & & $0.102 * *$ & & -0.012 & & 0.001 \\
\hline & & {$[0.022-0.182]$} & & {$[-0.092-0.068]$} & & {$[-0.077-0.079]$} \\
\hline $\begin{array}{l}\text { Joint Significance of both } \\
\text { periods ( } p \text {-value) }\end{array}$ & & 0.0000 & & 0.345 & & 0.194 \\
\hline Resistance to 2 nd and & $0.081 * *$ & $0.087^{* *}$ & $0.093 * * *$ & $0.088 * *$ & $0.075 * *$ & $0.078^{* *}$ \\
\hline 3rd gen. Fluoroquinolones & {$[0.012-0.151]$} & {$[0.013-0.160]$} & {$[0.025-0.161]$} & {$[0.017-0.160]$} & {$[0.007-0.143]$} & [0.007-0.149] \\
\hline \multirow{2}{*}{$(t-1)$} & & -0.019 & & -0.020 & & -0.029 \\
\hline & & {$[-0.093-0.054]$} & & {$[-0.092-0.052]$} & & {$[-0.100-0.042]$} \\
\hline $\begin{array}{l}\text { Joint Significance of both } \\
\text { periods ( } p \text {-value) }\end{array}$ & & 0.041 & & 0.034 & & 0.053 \\
\hline \multirow{2}{*}{$\begin{array}{l}\text { Resistance to Piperacilin/ } \\
\text { Tazobactam }\end{array}$} & 0.045 & $0.077 * *$ & 0.022 & 0.034 & 0.036 & 0.056 \\
\hline & {$[-0.022-0.112]$} & {$[0.008-0.146]$} & {$[-0.043-0.088]$} & {$[-0.033-0.102]$} & {$[-0.029-0.101]$} & {$[-0.011-0.123]$} \\
\hline \multirow[t]{2}{*}{$(t-1)$} & & 0.033 & & 0.023 & & 0.021 \\
\hline & & {$[-0.037-0.102]$} & & {$[-0.045-0.091]$} & & {$[-0.046-0.088]$} \\
\hline $\begin{array}{l}\text { Joint Significance of both } \\
\text { periods ( } p \text {-value) }\end{array}$ & & 0.076 & & & & 0.236 \\
\hline \multirow[t]{2}{*}{ Trend Variable } & & & & & $0.012 * * *$ & $0.011 * * *$ \\
\hline & & & & & {$[0.010-0.013]$} & [0.010-0.013] \\
\hline \multirow[t]{2}{*}{ Constant } & $4.172 * * *$ & $4.085^{* * *}$ & 0.204 & $0.942 * * *$ & $3.337^{* * *}$ & $3.387^{* * *}$ \\
\hline & [4.119 - 4.225] & [4.012 - 4.157] & {$[-0.477-0.886]$} & {$[0.286-1.598]$} & {$[3.249-3.425]$} & {$[3.289-3.484]$} \\
\hline $\begin{array}{l}\text { Joint Significance of all in- } \\
\text { dependent Variables ( } p \text {-value) }\end{array}$ & 0.000 & 0.000 & 0.000 & 0.003 & 0.000 & 0.001 \\
\hline Time Fixed Effects & No & No & Yes & Yes & No & No \\
\hline$N$ & 4,793 & 4,505 & 4,793 & 4,505 & 4,793 & 4,505 \\
\hline$R^{2}$ & 0.01 & 0.02 & 0.12 & 0.11 & 0.07 & 0.07 \\
\hline \multicolumn{7}{|c|}{$\begin{array}{l}\text { Notes: The regressions use monthly data on the application density (AD) of Carbapenems (Imipenem, Meropenem, Ertapenem } \\
\text { and Doripenem) from } 2001-2012 . \mathrm{RD} \text { is the resistance density defined as the resistant isolates per } 1000 \text { patient days. All } \\
\text { included resistance rate are for gram-negative pathogens only. P-values for the joint significance of independent variables were } \\
\text { calculated using Wald tests. } \mathrm{H}_{0} \text { is that the variables do not have an effect. The } 95 \% \text { confidence intervals are given in brackets. } \\
\text { *** Significant at the } 1 \text { percent level. }\end{array}$} \\
\hline
\end{tabular}


Table A8. Resistance Elasticity of Linezolid use (Resistance Density)

\begin{tabular}{|c|c|c|c|c|c|c|}
\hline \multirow{2}{*}{$\begin{array}{l}\text { Dependent Variable: } \\
\text { Linezolid AD(log) }\end{array}$} & \multicolumn{6}{|c|}{ Unit Fixed Effects } \\
\hline & 1 & 2 & 3 & 4 & 5 & 6 \\
\hline MRSA & $\begin{array}{c}0.183^{* * *} \\
{[0.127-0.239]}\end{array}$ & $\begin{array}{c}0.201^{* * *} \\
{[0.141-0.261]}\end{array}$ & $\begin{array}{c}0.191^{* * *} \\
{[0.136-0.246]}\end{array}$ & $\begin{array}{c}0.203^{* * *} \\
{[0.145-0.262]}\end{array}$ & $\begin{array}{c}0.204^{* * *} \\
{[0.150-0.259]}\end{array}$ & $\begin{array}{c}0.224 * * * \\
{[0.166-0.282]}\end{array}$ \\
\hline$(t-1)$ & & $\begin{array}{c}0.062^{* *} \\
{[0.001-0.123]}\end{array}$ & & $\begin{array}{c}0.067^{* *} \\
{[0.008-0.126]}\end{array}$ & & $\begin{array}{c}0.085^{* * *} \\
{[0.026-0.143]}\end{array}$ \\
\hline $\begin{array}{l}\text { Joint Significance of both } \\
\text { periods ( } p \text {-value) }\end{array}$ & & 0.000 & & 0.000 & & 0.000 \\
\hline VRE & $\begin{array}{c}0.471 * * * \\
{[0.329-0.614]}\end{array}$ & $\begin{array}{c}0.537 * * * \\
{[0.385-0.689]}\end{array}$ & $\begin{array}{c}0.312^{* * *} \\
{[0.170-0.453]}\end{array}$ & $\begin{array}{c}0.298 * * * \\
{[0.148-0.449]}\end{array}$ & $\begin{array}{c}0.305^{* * *} \\
{[0.165-0.445]}\end{array}$ & $\begin{array}{c}0.295 * * * \\
{[0.146-0.444]}\end{array}$ \\
\hline$(t-1)$ & & $\begin{array}{c}0.417^{* * *} \\
{[0.266-0.568]}\end{array}$ & & $\begin{array}{c}0.163 * * \\
{[0.014-0.312]}\end{array}$ & & $\begin{array}{c}0.177^{* *} \\
{[0.030-0.325]}\end{array}$ \\
\hline $\begin{array}{l}\text { Joint Significance of both } \\
\text { periods ( } p \text {-value) }\end{array}$ & & 0.000 & & 0.000 & & 0.000 \\
\hline Trend Variable & & & & & $\begin{array}{c}0.019 * * * \\
{[0.017-0.021]}\end{array}$ & $\begin{array}{c}0.019 * * * \\
{[0.017-0.021]}\end{array}$ \\
\hline Constant & $\begin{array}{c}1.934 * * * \\
{[1.866-2.002]}\end{array}$ & $\begin{array}{c}1.806 * * * \\
{[1.708-1.905]}\end{array}$ & $\begin{array}{c}0.540 \\
{[-0.114-1.193]}\end{array}$ & $\begin{array}{c}0.645^{*} \\
{[-0.047-1.336]}\end{array}$ & $\begin{array}{c}0.355^{* * *} \\
{[0.218-0.492]}\end{array}$ & $\begin{array}{c}0.241 * * * \\
{[0.077-0.405]}\end{array}$ \\
\hline $\begin{array}{l}\text { Joint Significance of all in- } \\
\text { dependent Variables ( } p \text {-value) }\end{array}$ & 0.000 & 0.000 & 0.000 & 0.000 & 0.000 & 0.000 \\
\hline Time Fixed Effects & No & No & Yes & Yes & No & No \\
\hline$N$ & 4,224 & 3,755 & 4,224 & 3,755 & 4,224 & 3,755 \\
\hline$R^{2}$ & 0.02 & 0.03 & 0.15 & 0.16 & 0.10 & 0.11 \\
\hline $\begin{array}{l}\text { Notes: The regressions includes } \\
\text { density defined as the resistant } \\
95 \% \text { confidence intervals are gi } \\
\text { Wald tests. } \mathrm{H}_{0} \text { is that the variab } \\
\text { *** Significant at the } 1 \text { percent } \\
\text { ** Significant at the } 5 \text { percent I } \\
\text { * Significant at the } 10 \text { percent I }\end{array}$ & $\begin{array}{l}\text { monthly data or } \\
\text { isolates per } 100 \\
\text { ven in brackets. } \\
\text { les do not have a } \\
\text { level. } \\
\text { evel. } \\
\text { evel. }\end{array}$ & $\begin{array}{l}\text { in the application } \\
0 \text { patient days. A } \\
\text { P-values for the } \\
\text { an effect. }\end{array}$ & $\begin{array}{l}\text { n density }(A D) \text { of } \\
\text { All included resist } \\
\text { joint significance }\end{array}$ & $\begin{array}{l}\text { Linezolid from } 20 \\
\text { ance rate are for } \\
\text { of independent }\end{array}$ & $\begin{array}{l}001-2012 . R D \text { is } \\
\text { gram-negative } p \\
\text { variables were c }\end{array}$ & $\begin{array}{l}\text { the resistance } \\
\text { athogens only. } \\
\text { alculated using }\end{array}$ \\
\hline
\end{tabular}


Table A9. Resistance Elasticity of Glycopeptide use (Resistance Density)

\begin{tabular}{|c|c|c|c|c|c|c|}
\hline \multirow{2}{*}{$\begin{array}{l}\text { Dependent Variable: } \\
\text { Glycopeptide AD (log) }\end{array}$} & & & & & & \\
\hline & 1 & 2 & 3 & 4 & 5 & 6 \\
\hline MRSA & $\begin{array}{c}0.150 * * * \\
{[0.096-0.204]}\end{array}$ & $\begin{array}{c}0.174 * * * \\
{[0.116-0.232]}\end{array}$ & $\begin{array}{c}0.159 * * * \\
{[0.105-0.214]}\end{array}$ & $\begin{array}{c}0.188^{* * *} \\
{[0.129-0.247]}\end{array}$ & $\begin{array}{c}0.153 * * * \\
{[0.099-0.207]}\end{array}$ & $\begin{array}{c}0.178 * * * \\
{[0.120-0.236]}\end{array}$ \\
\hline$(\mathrm{t}-1]$ & & $\begin{array}{c}0.059 * * \\
{[0.001-0.117]}\end{array}$ & & $\begin{array}{c}0.045 \\
{[-0.014-0.104]}\end{array}$ & & $\begin{array}{c}0.064^{* *} \\
{[0.006-0.122]}\end{array}$ \\
\hline $\begin{array}{l}\text { Joint Significance of both } \\
\text { periods ( } p \text {-value) }\end{array}$ & & 0.000 & & 0.000 & & 0.000 \\
\hline CNS & $\begin{array}{c}0.218 * * * \\
{[0.138-0.299]}\end{array}$ & $\begin{array}{c}0.230 * * * \\
{[0.143-0.317]}\end{array}$ & $\begin{array}{c}0.215^{* * *} \\
{[0.133-0.296]}\end{array}$ & $\begin{array}{c}0.218^{* * *} \\
{[0.130-0.306]}\end{array}$ & $\begin{array}{c}0.230 * * * \\
{[0.149-0.310]}\end{array}$ & $\begin{array}{c}0.236 * * * \\
{[0.150-0.323]}\end{array}$ \\
\hline$(\mathrm{t}-1]$ & & $\begin{array}{c}0.105 * * \\
{[0.018-0.192]}\end{array}$ & & $\begin{array}{c}0.102 * * \\
{[0.014-0.190]}\end{array}$ & & $\begin{array}{c}0.112 * * \\
{[0.025-0.198]}\end{array}$ \\
\hline $\begin{array}{l}\text { Joint Significance of both } \\
\text { periods ( } p \text {-value) }\end{array}$ & & 0.000 & & 0.000 & & 0.000 \\
\hline Trend Variable & & & & & $\begin{array}{c}0.006 * * * \\
{[0.004-0.008]}\end{array}$ & $\begin{array}{c}0.007 * * * \\
{[0.005-0.009]}\end{array}$ \\
\hline Constant & $\begin{array}{c}2.426 * * * \\
{[2.327-2.525]}\end{array}$ & $\begin{array}{c}2.128 * * * \\
{[1.973-2.283]}\end{array}$ & $\begin{array}{c}-0.203 \\
{[-0.716-0.310]}\end{array}$ & $\begin{array}{c}-0.756 * * * \\
{[-1.265--0.247]}\end{array}$ & $\begin{array}{c}1.944 * * * \\
{[1.801-2.086]}\end{array}$ & $\begin{array}{c}1.565 * * * \\
{[1.374-1.757]}\end{array}$ \\
\hline $\begin{array}{l}\text { Joint Significance of all } \\
\text { independent Variables. ( } p \text { - } \\
\text { value) }\end{array}$ & 0.000 & 0.000 & 0.000 & 0.000 & 0.000 & 0.000 \\
\hline Time Fixed Effects & No & No & Yes & Yes & No & No \\
\hline$N$ & 4,130 & 3,553 & 4,130 & 3,553 & 4,130 & 3,553 \\
\hline$R^{2}$ & 0.01 & 0.02 & 0.07 & 0.08 & 0.02 & 0.03 \\
\hline
\end{tabular}

Notes: The regressions uses monthly data on the application density (AD) of Glycopetides (Vancomycin and Teicoplanin) from 2001 - 2012. MRSA rates gives the density of S.aureus isolates resistant to Oxacillin per 1000 patient days. CNS is the incidence of coagulase-negative staphylococcus as measured in tested isolates. $95 \%$ confidence intervals are given in brackets. P-values for the joint significance of independent variables were calculated using Wald tests. $\mathrm{H}_{0}$ is that the variables do not have an effect.

*** Significant at the 1 percent level.

** Significant at the 5 percent level.

* Significant at the 10 percent level 
Table A10. Resistance Elasticity of Carbapenem use, restricted model

\begin{tabular}{|c|c|c|c|c|c|c|}
\hline \multirow{2}{*}{$\begin{array}{l}\text { Dependent Variable } \\
\text { Carbapenem AD (log) }\end{array}$} & \multicolumn{6}{|c|}{ Unit Fixed Effects } \\
\hline & 1 & 2 & 3 & 4 & 5 & 6 \\
\hline Resistance to 2 nd and & $0.252 * * *$ & $0.375^{* * *}$ & $0.152^{* *}$ & $0.172^{* *}$ & 0.122 & $0.162^{* *}$ \\
\hline 3rd gen. Fluoroquinolones & $(0.098-0.405)$ & $(0.210-0.540)$ & $(0.000-0.303)$ & $(0.010-0.333)$ & $(-0.028-0.272)$ & $(0.002-0.322)$ \\
\hline \multirow[t]{2}{*}{$(\mathrm{t}-1)$} & & $0.181^{* *}$ & & -0.013 & & -0.023 \\
\hline & & $(0.012-0.351)$ & & $(-0.179-0.152)$ & & $(-0.187-0.141)$ \\
\hline Joint Significance of both & & 0.000 & & 0.098 & & 0.110 \\
\hline periods (p-value] & & & & & & \\
\hline \multirow[t]{2}{*}{ Trend Variable } & & & & & $0.012 * * *$ & $0.012 * * *$ \\
\hline & & & & & $(0.011-0.014)$ & $(0.011-0.014)$ \\
\hline \multirow[t]{2}{*}{ Constant } & $4.328 * * *$ & $4.290 * * *$ & -0.066 & $1.276^{* * *}$ & $3.378 * * *$ & $3.398 * * *$ \\
\hline & $(4.291-4.365)$ & $(4.244-4.336)$ & $(-0.900-0.768)$ & ) $(0.493-2.058)$ & $(3.302-3.454)$ & $(3.318-3.477)$ \\
\hline Time Fixed Effects & No & No & Yes & Yes & No & No \\
\hline$N$ & 5,245 & 5,023 & 5,245 & 5,023 & 5,245 & 5,023 \\
\hline$R^{2}$ & 0.00 & 0.00 & 0.12 & 0.12 & 0.08 & 0.08 \\
\hline
\end{tabular}

Notes: The regressions include monthly data on the application density (AD) of carbapenems (Imipenem, meropenem, ertapenem and doripenem) from 2001 - 2012. Resistance is measured as the resistance rate: resistant isolates as a proportion of all tested isolates. All included resistance rate are for gram-negative pathogens only. The $95 \%$ confidence intervals are given in brackets.

*** Significant at the 1 percent level.

** Significant at the 5 percent level.

* Significant at the 10 percent level. 